\title{
SARS-CoV-2 interacts with renin-angiotensin system: impact on the central nervous system in elderly patients
}

\author{
Jorge Quarleri $\mathbb{D}^{\circ}$ M. Victoria Delpino
}

Received: 22 December 2021 / Accepted: 8 February 2022 / Published online: 14 February 2022

(C) The Author(s), under exclusive licence to American Aging Association 2022

\begin{abstract}
SARS-CoV-2 is a recently identified coronavirus that causes the current pandemic disease known as COVID-19. SARS-CoV-2 uses angiotensin-converting enzyme 2 (ACE2) as a receptor, suggesting that the initial steps of SARS-CoV-2 infection may have an impact on the renin-angiotensin system (RAS). Several processes are influenced by RAS in the brain. The neurological symptoms observed in COVID-19 patients, including reduced olfaction, meningitis, ischemic stroke, cerebral thrombosis, and delirium, could be associated with RAS imbalance. In this review, we focus on the potential role of disturbances in the RAS as a cause for central nervous system sequelae of SARS-CoV-2 infection in elderly patients.
\end{abstract}

Keywords COVID-19 - SARS-CoV-2 $\cdot$ Central nervous system $\cdot$ Renin-angiotensin system $\cdot$ Elderly

J. Quarleri $(\bowtie) \cdot$ M. V. Delpino $(\bowtie)$

Instituto de Investigaciones Biomédicas en Retrovirus Y

Sida (INBIRS), Universidad de Buenos Aires-CONICET,

Paraguay 2155-Piso 11 (1121), Buenos Aires, Argentina

e-mail: quarleri@fmed.uba.ar

M. V. Delpino

e-mail: mdelpino@ffyb.uba.ar

\section{Introduction}

Coronaviruses are positive single-strand RNA viruses, 80-220 $\mathrm{nm}$ in size, pleomorphic although often spherical, and enveloped with crown-shaped glycoprotein spikes, that comprise three genera: alphacoronavirus, betacoronavirus, and gammacoronavirus [1]. SARS-CoV-2, a betacoronavirus, has caused a global pandemic that started in 2019 [2]. While the pathogenesis of SARS-CoV-2 remains under study, common findings with SARS-CoV-1 and MERS-CoV pathogenesis may offer insights into SARS-CoV-2 pathogenesis. Most coronaviruses are largely associated with respiratory infections. SARS-CoV-2 infection results in a series of symptoms comprising fever, pulmonary insufficiency, dry cough, myalgia, headache, and intestinal dysfunction [3]. The complications and loss of function through the affected organs are particularly exacerbated in patients with co-morbidities [4].

Reports of a wide range of neurologic symptoms including stroke [5-7], viral presence in the cerebrospinal fluid (CSF) [8], and brain tissues from autopsies [9-11] introduced a neuroinvasiveness potential of SARS-CoV-2. It is increasingly evident that SARS-CoV-2 is not only neurotropic but also associated with a much broader spectrum of acute and atypical neurological syndromes and manifestations than prior infections, particularly those involving $\beta$-coronaviruses [12-17]. 
The genome of SARS-CoV-2 is $79.5 \%$ similar to previous SARS-CoV [18-20]. The most important structural proteins are the spike (S), envelope (E), matrix (M), and nucleocapsid (N) [19, 21]. Despite similarities in their genomes, a remarkable difference is the longer length of the $\mathrm{S}$ glycoprotein present in SARS-CoV-2 as compared to other coronaviruses [21]. It has been hypothesized that the higher transmissibility of SARS-CoV-2 is due to this difference in the $S$ protein [21].

Angiotensin-converting enzyme 2 (ACE2) serves as a receptor for SARS-CoV-2 entry into susceptible cells of multiple organs [22]. The ubiquitous expression of ACE2 in multiple cell types allows SARS-CoV-2 to infect different organs including the nasopharynx, lungs, lymph nodes, small intestine, stomach, spleen, kidney, and brain leading to multiple organ damage [23]. The trimeric S glycoprotein interacts with the human ACE2 to allow for viral entry into host cells by viral membrane fusion. The affinity of the interaction between SARS-CoV-2 S glycoprotein and ACE2 is 10 to 20-fold higher than SARS$\mathrm{CoV}$, and this increased affinity is critical for the neuroinvasiveness of SARS-CoV-2 [19, 24, 25]. Viral fusion is helped by prior proteolytic cleavage of $\mathrm{S}$ by the transmembrane protease serine 2 (TMPRSS2), or by cathepsin B and L [22]. Hence, TMPRSS2 mediates spike protein activation and promotes SARSCoV-2 entry via direct fusion, thereby subverting entry through endocytosis [26]. Moreover, TMPRSS2 or TMPRSS4 can generate circulating ACE2 by cleavage of the membrane-bound protein in vascular endothelial cells. Once ACE2 is shed, SARS-CoV-2 entry may occur by TMPRSS2 and TMPRSS4-mediated endocytosis [27].

Furin is a pro-protein convertase present in multiple tissues, including the brain. At the intracellular level, furin cleaves the viral $\mathrm{S}$ protein to a mature form, thus reinforcing its receptor binding and membrane fusion capabilities, therefore contributing to the multi-organ involvement particularly where ACE2 expression level is low [28].

Several other molecules have been reported as SARS-CoV-2 cellular receptors and proteases that mediate viral entry [29, 30]. For epithelial cells, these proteases may assist viral entry through non-ACE2mediated routes such as a pathway involving the CD147-spike protein and CD26, which is expressed ubiquitously [31, 32].
ACE2 is a key component of the renin-angiotensin system (RAS), which plays an essential role in the homeostatic regulation of blood pressure, electrolyte, and fluid balance, as well as in the regulation of vital organ function by the renal and cardiovascular system [33].

The SARS-CoV-2-ACE2 interaction links viral pathogenesis to the function of the renin-angiotensin system (RAS). In the brain, there are a circulating RAS and a local one. The former exerts its effect in circumventricular organs that lack the blood-brain barrier (BBB) and project to nuclei in the hypothalamus and medulla. The brain RAS synthesize de novo all components, but independently of the circulatory RAS [34].

The brain RAS may actively participate in the modulation of neurotransmitter release [35-37], and therefore, it is thought to control blood pressure and regulate metabolism [38, 39]. Besides its role in normal organ development and function, RAS appears to be involved in age-associated organ dysfunction by promoting pathophysiological processes of various age-related disorders. These include heart failure and other cardiovascular diseases, diabetes, cancer, chronic kidney disease, osteoporosis, and dementia [40]. In line with these observations, Benigni et al. reported that normative aging may be delayed by inhibiting RAS [41], probably through the decrease of oxidative stress and upregulation of prosurvival genes [42].

Thus, SARS-CoV-2 infection and age-associated dysregulation of the RAS may contribute to adverse clinical outcomes. In this review, we focus on the potential role of disturbances in RAS as a cause for central nervous system sequelae of SARS-CoV-2 infection in elderly patients.

\section{SARS-CoV-2 and the CNS}

Coronavirus disease 2019 (COVID-19) patients can present neurological symptoms including reduced or total incapacity to detect odors and/or flavors, meningitis, ischemic stroke, cerebral thrombosis, sickness, delirium, and Guillain-Barré syndrome [43]. Some of these syndromes promote high in-hospital mortality, probably due to dysregulation of components of the central and peripheral nervous systems. Disturbance of nervous system function by SARS-CoV-2 infection 
may impair multiple systemic cellular, tissue, and organ regulatory mechanisms, resulting in the varied symptomatology of COVID-19.

It appears that the brain may constitute a replicative niche for SARS-CoV-2 [44]. Examination of brain tissues from post-mortem SARS-CoV-2-infected patients revealed the presence of virus in brain capillaries, endothelial cells, pericytes, and neurons $[9,45,46]$. SARS-CoV-2 was also found in areas of the cardiorespiratory center and medulla, suggesting that infection of these brain areas may lead to or contribute to respiratory failure in COVID-19 patients [47]. Moreover, SARS-CoV-2 was detected in the cerebrospinal fluid (CSF) of patients with acute neurological symptoms, like seizures or encephalitis in conjunction with magnetic resonance image findings on the condition [8,48]. Furthermore, viral antigens were detected in the CSF of COVID-19 patients [8, 49]. Analysis of CSF also revealed the presence of SARS-CoV-2-specific antibodies, which hypothesized that auto-antigenicity may underlie post-infectious autoimmune demyelinated pathology of the brain in COVID-19 patients [50, 51].

Infection of the CNS by SARS-CoV-2 is possible due to ACE2 expression in neurovasculature, choroid plexus, ventricles, and substantia nigra, as well as in astrocytes, oligodendrocytes, and neurons, but not in microglia [52]. Nevertheless, ACE2 expression is relatively high in some neurovascular unit components, particularly in brain pericytes; these cells are derived from neural crest stem cells and are physically linking endothelial and astrocytic cells, thus promoting its maturation and production of basement membrane components [53]. Using cortical organoids as a model, pericyte-like cells (PLCs) are permissive of infection with authentic SARS-CoV-2 and have been proposed to serve as viral "replication hubs," able to spread the virus to astrocytes and mediating inflammatory type I interferon transcriptional responses [54].

The structural changes in cerebral small vessels of patients with COVID-19 and consequent neurological symptoms have been associated with direct viral damage of infected brain endothelial cells mediated by SARS-CoV-2's main protease [55]. Indeed, virus progeny release into the CNS has been associated with intracranial hypertension and edema that further contribute to increasing its neuroinvasiveness [56, 57].
Studies performed in vitro using human brain organoids and neurons suggest that SARS-CoV-2 infection promotes cell proliferation, metabolic processes, and organelle fission, suggesting that the brain is a site of replication for SARS-CoV-2 through a mechanism that involves reduction of interferon-driven gene activation. The observed reduction in interferonmediated responses following SARS-CoV-2 infection may also result from signaling emanating by infected neurons that promote the death of neighboring cells [44].

Infection of the central nervous system by SARSCoV-2 could be achieved by several routes: (i) the hematogenous route followed by a breakdown of the blood-brain barrier (BBB); (ii) through the bloodcerebrospinal fluid barrier (BCSFB); (iii) following retrograde axonal transport of SARS-CoV-2 virions and trans-synaptic viral spreading; and (iv) through entry to circumventricular organs.

Early during infection, SARS-CoV-2 enters the bloodstream after primary infection of type II alveolar epithelial cells in the airway and, to a lesser extent, after infection of enterocytes at the gastrointestinal tract. Both sites that support the initial phase of viral replication are characterized by the high expression levels of ACE2. Later during infection, bloodstream invasion by the virus may increase when endothelial cells of the BBB or BCSFB are infected and disrupted, allowing for paracellular transmigration of virions. This route of viral propagation involves intercellular adhesion molecule 1 (ICAM1)-mediated transport that is upregulated by tumor necrosis factor-alpha (TNF- $\alpha$ ) and matrix metalloproteinases activation, which promote destabilization or disruption of tight junctions of the BBB leading to BBB leakage [9, 23, 47, 58-62]. Potent activation of the immune system known as "cytokine storm" is a state characterized by prominent overproduction and release of numerous active soluble components, such as interferons -IFN-, chemokines, interleukins -IL-, and TNF- $\alpha$. The discharge of excessive amounts of pro-inflammatory cytokines (i.e., IFN-I, IFN-II, IL-1 $\beta$, IL-6, IL-12, IL-18, IL-33, TNF- $\alpha$, TGF- $\beta$ ) and chemokines (i.e., CXCL-8, 10, CCL-2, CCL-3, and CCL-5) is responsible for an abnormal systemic inflammatory response, which afterward causes acute respiratory distress syndrome and organ failure [63], including an exacerbation of BBB breakdown and CNS dissemination [64-67]. 
Another route that SARS-CoV-2 may use to access CNS may be via the brain lymphatic drainage system. The presence of viral nucleotide sequences in macrophages and $\mathrm{T}$ lymphocytes distributed at the periphery of germinal centers, lymph nodes, and in peripheral blood suggests that SARS-CoV-2 could use a "Trojan horse"-type mechanism by infecting $\mathrm{T}$ lymphocytes, macrophages, and monocytes in the blood. Viremia in the circulation may be exacerbated by productive infection of peripheral endothelial cells [68-71].

Like other human coronaviruses, SARS-CoV-2 infection may occur via the BCSFB. The CSF circulation involves a local fluid exchange between blood, interstitial fluid, and CSF that occurs normally by directional and pulsatile flow through the brain [72]. Cells at the BCSFB may activate the expression of transcriptional factors (i.e., NF-kB) and metalloproteinases that can promote BCSFB permeability and immune cell trafficking, potentially leading to a neuroinflammatory environment [73].

SARS-CoV-2 may also reach the CNS through retrograde axonal transport and transneuronal spread from different nerves, allowing the virus to infect the brainstem and disseminate in the forebrain through neuroanatomically interconnected pathways [74]. SARS-CoV-2 spread through trans-synaptic transfer may involve exocytosis/endocytosis mechanisms or rapid axonal transport, which would move the virus along microtubules to the neuronal soma $[75,76]$. The transneuronal pathway is one of the potential routes that would allow SARS-CoV-2 to enter the CNS through primary sensory neurons. In this scenario, SARS-CoV-2 could enter through the olfactory mucosa (causing anosmia), spread through the olfactory nerve, and reach the olfactory cortex [77, 78]. Likewise, the virus could also enter the CNS through neurons innervating exocrine tissues such as salivary and lacrimal glands, spread through the facial and glossopharyngeal nerves, and reach various brain stem nuclei. The SARS-CoV-2 infection could also spread from gustatory cells on taste buds (producing ageusia) and move retrogradely through nerves that end in the nucleus tractus solitarius of the brainstem [79]. Lastly, SARS-CoV-2 could also reach the brainstem through the vagus nerve through infection of terminals in the respiratory tract, allowing the virus to spread to other organs innervated by vagal terminals [80-82]. The nucleus of the solitary tract and the dorsal motor nucleus of the vagus nerve express ACE2 [83], but after SARS-CoV-2 infection, ACE2 expression decreases forcing toward ACE-Ang-II-AT1 receptor axis, dysregulation of anti-inflammatory response leading to a systemic inflammatory response that results in the elevation of pro-inflammatory cytokines, chemokines, acute phase proteins, complement, and modification of leukocyte profiles in blood with consequent disruption of BBB, and microglial activation which results in increased vascular permeability [84-86] (Fig. 1).

Finally, SARS-CoV-2 might enter the CNS through the highly vascularized circumventricular organs that express ACE2 such as the subfornical organ, or through the paraventricular nucleus of the hypothalamus, the nucleus of the solitary tract, and the rostral ventrolateral medulla that also express ACE2 [87]. These areas are expected to be permissive to SARSCoV-2 infection and thus could undergo neurovascular damage as a consequence of infection as discussed previously [88, 89]. The circumventricular organs and the areas of the hypothalamus and brainstem proximal to the third and fourth ventricles lack BBB and allow communication between the blood, the CSF, and the brain parenchyma [90].

\section{Renin-angiotensin system (RAS) in the CNS during SARS-CoV-2 infection}

RAS is a central mechanism of regulation of blood pressure that involves multiple organs including the brain, where its action impacts cerebral vasodilation, neuroprotection, and cognition [91]. RAS initiates in the kidney with the synthesis of the protease renin. This enzyme produces angiotensin I (Ang-I) by cleavage of its substrate angiotensinogen produced in the liver. Ang-I is not biologically active and is transformed in Ang-II mainly by the action of the angiotensin-converting enzyme (ACE). Ang (1-7) is subsequently produced by the action of angiotensinconverting enzyme 2 (ACE2) on Ang-II. RAS function is dependent on the balance of two opposing pathways: One involves ACE and its product Ang-II that signals through seven transmembrane-spanning G protein-coupled AT1 or AT2 receptors (AT1R and AT2R, respectively) based on their selective affinity for peptide and non-peptide ligands. Ang-II mediates biological functions of the RAS system and controls 


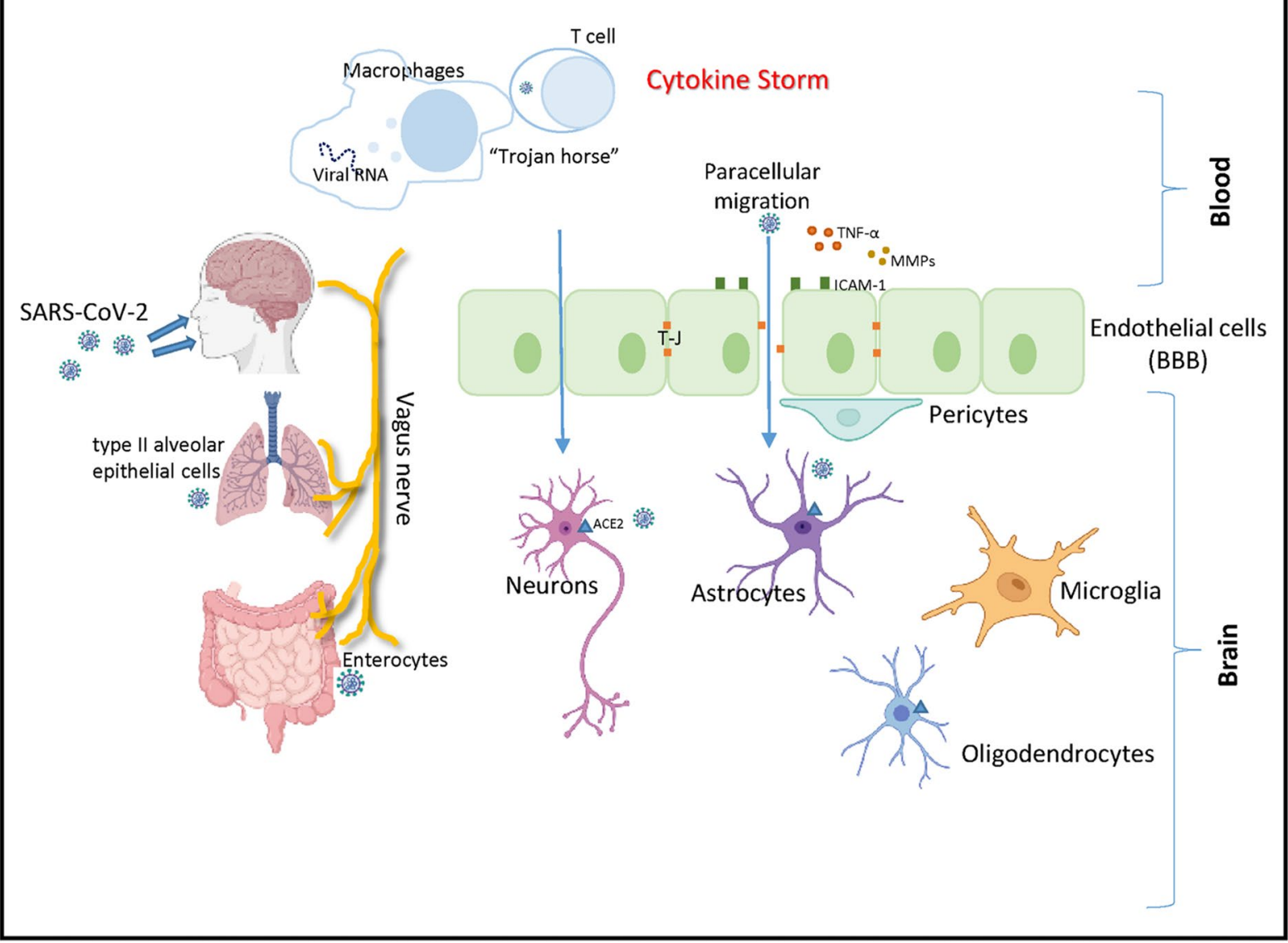

Fig. 1 Proposed routes of SARS-CoV2 neuroinvasion. Viruses enter the vascular pathways and spread toward the CNS through the vagus nerve branch that innervates the respiratory and gastrointestinal tract. SARS-CoV-2 could also enter the respiratory tract into the bloodstream through ACE2 receptors expressed in type II alveolar epithelial cells of the respiratory tract and also after infection of enterocytes at the gastrointestinal tract. Bloodstream invasion by the virus may increase when endothelial cells of the BBB are infected and cell-to-cell adhesion disrupted, allowing for paracellular trans-

physiological responses in the renal system. The alternative pathway involves ACE2, which mediates the hydrolysis of Ang-II into Ang (1-7), which binds to the Mas receptor (MasR with the highest affinity. The first pathway results in vasoconstriction and is pro-inflammatory and pro-thrombotic, and fibrotic; the second pathway is vasorelaxant, natriuretic, antithrombotic, anti-inflammatory, and anti-fibrotic through the actions of Ang (1-7) [92, 93].

Interestingly, an alternative renin isoform known as renin-b has been reported, supporting the migration of virions involving ICAM-1-mediated transport that is upregulated by TNF- $\alpha$ and MMPs activation, which promote destabilization or disruption of tight junctions of the BBB leading to BBB leakage that is exacerbated by the cytokine storm. Additionally, the presence of viral nucleotide sequences in macrophages and $\mathrm{T}$ lymphocytes distributed at the periphery of germinal centers, lymph nodes, and in peripheral blood suggests that SARS-CoV-2 could use a "Trojan horse"-type mechanism by infecting $\mathrm{T}$ cells, macrophages, and monocytes in the blood

existence of an intracrine RAS [94]. Renin-b is an alternative renin isoform transcribed in the brain but not present in other tissues [95, 96]. Catalytically active renin-b lacks a signal peptide and, as an intracellular form, it has been proposed to regulate brain RAS rather than generating intracellular Ang-II [97]. Whether Ang-II can be generated as a result of renin-b activity in presynaptic neurons to be subsequently released in presynaptic terminals upon depolarization is still unclear [97]. If this were the case, however, this pathway would involve a 
potential role of Ang-II as a neurotransmitter or a neuromodulator [98].

The role of the RAS and especially the implications of ACE2 activity in the brain have been explored only recently. However, the recently demonstrated influence of the Ang (1-7)/Mas pathway in neuronal plasticity suggests a role of ACE2 in CNS homeostasis [99].

SARS-CoV-2 entry into the brain activates microglia and induces astrogliosis, increasing the secretion of proinflammatory cytokines (TNF- $\alpha$, IL-6, and IL-1 $\beta$ ) and prostaglandin E2, leading to chronic inflammation, neural hyperexcitability, and exacerbated neuron programmed cell death [84, 100].

Levels of Ang-II are increased in SARS-CoV-2 infected patients. Increased Ang-II may lead to exacerbated inflammatory responses observed in COVID19 since Ang-II potently activates NF- $\kappa B$ in different cell types [101, 102]. An increase in activity of the Ang-II pathway would be more harmful in older patients because of its exacerbated inflammatory component [103]. Thus, activation of the Ang-II pathway may contribute to increased risk of mortality in older individuals with COVID-19 by exacerbating the impact of dysregulation of the immune system, which leads to hyper-inflammation [103]. Additionally, in patients that recover, peripheral inflammation during SARS-CoV-2 infection could have long-term consequences leading to CNS disorders such as neurodegenerative disease and dementia [104].

Ang (1-7) can induce endothelial and neuronal nitric oxide (NO) synthase (eNOS) activity through Ang (1-7)-Mas, and bradykinin-NO [105] signaling, increasing NO production [106], which promotes vasodilatation and apoptosis reduction [107, 108]. Ang (1-7)/Mas receptor signaling also inhibits inducible NO synthase (iNOS) in glial cells and neurons, thus reducing tissue damage by peroxynitrite [109, 110]. In the brain, NO release is required for neural processes including locomotor activity, memory, and learning [111]. Under physiological conditions, NO activates Akt and cyclic AMP-responsive-elementbinding protein (CREB), which are involved in survival pathways. Excess NO, on the other hand, leads to the formation of reactive nitrogen species which cause cell damage [112]. NO production is strongly associated with the activity of RAS, and in patients with COVID-19, some neurological signs could be associated with diminished physiological NO levels in the CNS [113].

Numerous reports have shown that the brain ACE2-Ang-(1-7)-MasR axis acted as a pivotal regulator of blood pressure, counteracting the pressor effect of ACE-Ang-II-AT1R [114]. Increased levels of oxidative stress and proinflammatory cytokines prompted to favor and maintain hypertension through activating redox signaling in the blood pressure regulatory centers. In this sense, in vitro and in vivo studies have revealed that inhibition of oxidative stress and inflammation may represent part of the underlying mechanisms for the antihypertensive effects of ACE2-Ang-(1-7)-MasR axis [115, 116] (Fig. 2).

In the bloodstream, the level of soluble ACE2 is normally lower than $17 \mathrm{mU} / \mathrm{L}[117,118]$ but becomes elevated in different cardiovascular disorders [117-120]. Probably promoted by the SARSCoV-2 infection, it is also raised among patients with severe COVID-19 [121], which could be more pronounced among older patients [86, 119, 122-124]. However, contradictory results have been reported regarding circulating ACE2 activity in SARSCoV-2 infected patients that is ranging from elevated [125-131] to unchanged [132, 133] or even lowered circulating ACE2 levels [134]. Particularly in the brain, overactive RAS is associated with decreased cellular ACE2 level and activity during the development of neurogenic hypertension. Among patients, increased shedding of ACE2 takes place as indicated by its increased activity in their CSF samples. Such phenomenon involves the ADAM17, a member of the "A Disintegrin And Metalloproteases" (ADAM) family known to cleave a variety of membrane-anchored proteins, including ACE2. In the central nervous system, the AT1R on neurons mediates the ADAM17 upregulation upon brain RAS over-activation, leading to increased shedding of ACE2 and favoring the development of neurogenic hypertension and compromising the compensatory effect of Ang (1-7) [135]. However, the level of circulating ACE2 in the CSF in patients hospitalized with COVID-19 remains unknown.

Previous evidence obtained from SARS-CoV-1 patients indicates that SARS-CoV-2 infection can down-modulate ACE2 expression [136-139]. Considering that ACE2 mediates the Ang (1-7) production, it is expectable that SARS-CoV-2-mediated ACE2 downregulation will reduce Ang (1-7) production. 


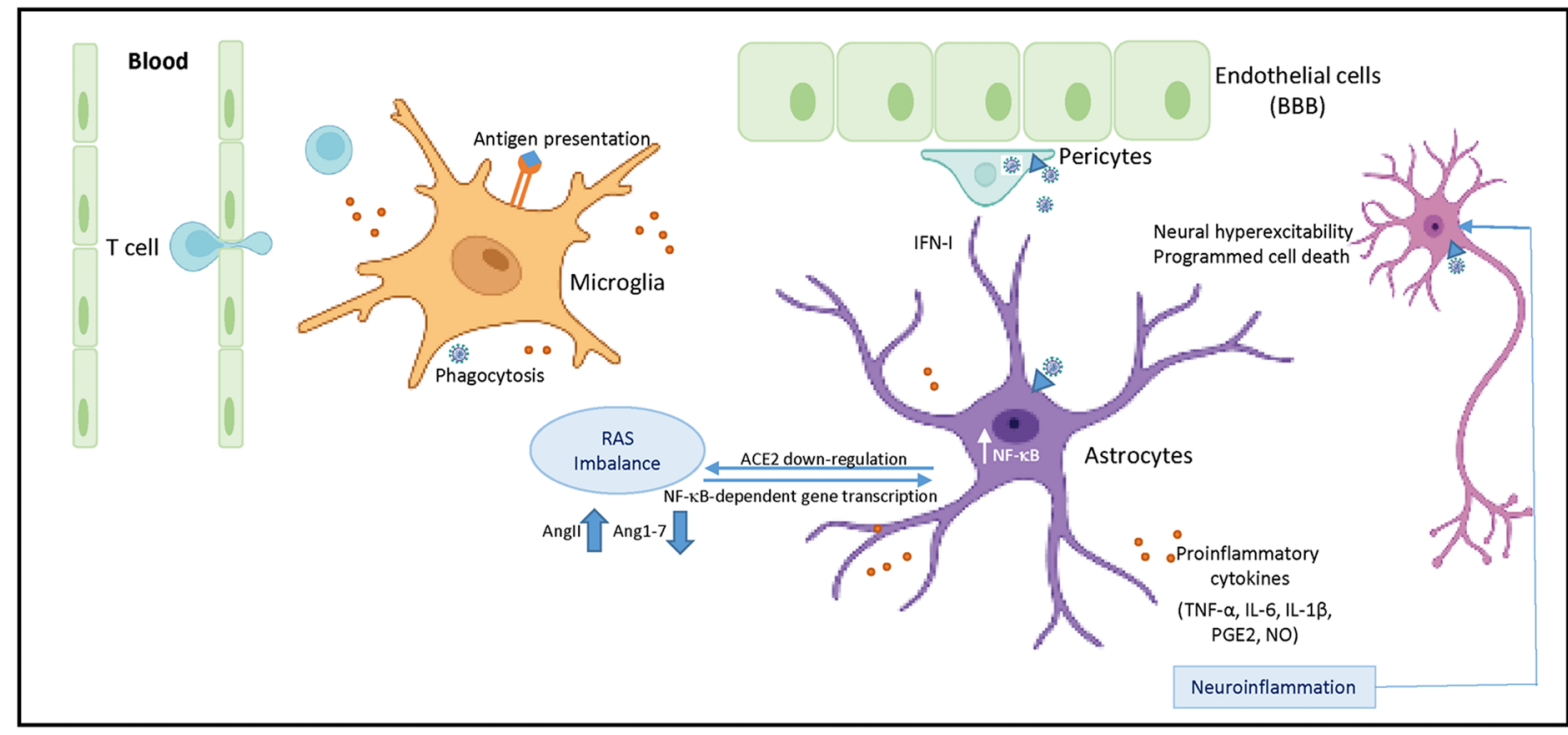

Fig. 2 SARS-CoV-2 entry into the brain activates microglia and induces astrogliosis, increasing the secretion of proinflammatory cytokines (TNF- $\alpha$, IL-6, and IL-1 $\beta$ ) and prostaglandin E2 (PGE2), leading to chronic inflammation, neural hyperexcitability, and exacerbated neuron programmed cell death. Levels of Ang-II are increased lead to exacerbated inflammatory responses observed in COVID-19 since Ang-II potently acti-

There is cumulative evidence that the ACE2-Ang (1-7)-MasR axis in the brain exerts mainly beneficial effects against hypertension [114], atherosclerosis [140] and antithrombotic activity [141]. The Mas receptor concentration is high not only in the brain structures associated with memory and cognition such as the hippocampus but also in the piriform cortex involved in smell being observed in neurons, astrocytes, and endothelial cells of cerebral resistance vessels [142-145]. As an endogenous constituent of the brain, Ang (1-7) is detected in the hypothalamus, medulla oblongata, and amygdale [146]. Consequently, when the ACE2 expression is decreasing after its SARS-CoV-2 interaction, a deleterious effect on the ACE2-Ang (1-7)-MasR axis becomes prominent with an impaired endothelial function in cerebral arteries and oxidative damage [147], difficulties in learning and memory [145, 148, 149], and reduced antioxidant and anti-inflammatory actions [146, 150, 151] [152].

RAS also regulates stress and anxiety responses. Transgenic mice with increased ACE2 expression display behaviors consistent with reduced anxiety levels [153]. This outcome was reversed when mice vates NF-kB in different cell types. An increase in activity of the Ang-II pathway would be more harmful in older patients because of its exacerbated inflammatory component which leads to hyper-inflammation. ACE2 expression is also high in brain pericytes that could be permissive of infection with SARS-CoV-2 and able to spread the virus to astrocytes mediating inflammatory interferon-type I (IFN-I) transcription

were treated with a Mas receptor antagonist, suggesting the Ang (1-7)/Mas axis in the regulation of anxiety. In addition, overexpression of ACE2 in mice reduces levels of cortisone and proopiomelanocortin in plasma, indicating that ACE2 may modulate basal anxiety levels through actions on the hypothalamic-pituitary-adrenal (HPA) axis [154-157]. SARS-CoV-2-mediated shedding of ACE2 may favor anxiety as well as depressive symptoms. Expectedly, disturbance of the HPA and the subsequent hypocortisolism seen in SARS-CoV-1 patients has been associated with increased anxiety, depression, and posttraumatic stress disorder [158]. In the RAS pathway, a stress response system similar to the HPA axis is triggered by Ang-II - as a stress hormone - binding to AT receptors located in the HPA axis, hippocampus, and prefrontal cortex [159]. Such HPA response to stress is desensitized using ACE inhibitors [160].

An increasingly large body of evidence suggests that the ACE2/Ang (1-7)/Mas receptor pathway results in the generation of protective mediators in numerous neuropsychiatric pathologies and stress disorders [110, 145, 154, 161]. The anti-inflammatory and antithrombotic effect of the activity of the ACE2/ 
Ang (1-7)/Mas receptor pathway in the CNS reduces both oxidative stress and apoptosis [162, 163]. Experiments in mice revealed that the administration of Ang (1-7) reduced not only the level of Ang-II but also hormones associated with stress response such as norepinephrine, dopamine, and serotonin (87).

\section{Age-related changes in the brain RAS}

RAS is imbalanced during aging due to changes in levels of its components. Changes in RAS during the aging result in abnormal levels of inflammation, oxidative stress, and cell death that promote chronic age-related disorders. Several studies have shown that Ang-II mediates premature senescence [164, 165]. Benigni et al. have shown increased longevity by downregulation of AT1R, which attenuated oxidative stress and promoted expression of pro-survival genes $[41,166]$.

Age-dependent variations in RAS components are differently controlled in circulating and brain RAS [167].

The mitochondrial and nuclear AT1R levels increased significantly with age $[168,169]$ as opposed to decreased AT2R expression [170] which achieves its maximal expression in developing fetal tissues but decreases later reaching lower levels in adulthood [171]. Similarly, age-related alterations in the distribution of RAS have been documented in the brain. A progressive decrease in the expression of AT2Rs and mRNA/protein expression of other protective RAS receptors accompanied by elevated Ang-II and AT1R levels with aging was shown in the substantia nigra [172]. Similarly, protective Ang (1-7)/MasR axis expression may be decreased in the brain of aged rats [143, 173] (Fig. 3).

Mitochondrial dysfunction has a critical role in cellular aging [174]. A functional mitochondrial angiotensin system has been identified that exhibits distributional changes in their RAS receptor levels with aging such as a decrease in AT2R and an increase in AT1R density [168]. Mitochondria in human skeletal muscle cells and monocytes as well as mouse cardiac myocytes, renal tubular cells, neuronal cells, vascular endothelial cells, and hepatocytes express high levels of AT1R with aging, which increases mitochondrial ROS levels, leading to diminished mitochondrial integrity, lowered ATP generation, and further overproduction of ROS, a prominent molecular mediator of aging [175]. Increased ROS levels lead to oxidation of mitochondrial macromolecules and DNA damage, both linked to cellular senescence and apoptosis [175, 176]. Excessive ROS production promotes the uncoupling of endothelial NO synthase, which in turn reduces NO availability and enhances ROS production. Under physiological conditions, the Ang-II capability to propitiate oxidative stress is firmly regulated. At variance, uncontrolled Ang-II-dependent ROS generation takes place as a consequence of ageassociated activation of RAS. This increased Ang-II level is associated with cellular senescence depicted by cardinal markers such as telomere shortening and cell cycle arrest, which are reversed by losartan [177]. Consistent with these observations, over-activation of the Ang-II/AT1R/NADPH-oxidase complex (NOX) axis in the brain results in increased oxidative stress and cellular dysfunction. Oxidative imbalance in this system is associated with diminished levels of sirtuin-3 (SIRT3) which suppress the pro-oxidative RAS axis [178]. Additionally, the uncoupling of endothelial NOS by superoxide anions may occur, thus decreasing NO availability and NOS activity with aging [179].

Upregulated AT1R but reduced AT2R expression impairs the counterbalance mechanism of the RAS in the aging brain while oxidative stress, neuroinflammation, and increased neuron vulnerability continue $[180,181]$. It has been suggested that RAS imbalance leads to age-related pro-inflammatory changes known as "inflammaging," observed in several tissues during aging [180].

Vascular cognitive impairment is a consequence of cerebrovascular disease characterized by brain dysfunction and cognitive loss [182]. Aging and hypertension are major risk factors for vascular cognitive impairment. Aging and hypertension are associated with poor blood flow with consequent hypoperfusion and hypoxia. These conditions generate a prooxidative and pro-inflammatory milieu in the brain, which may promote neuronal death, thus contributing to cognitive impairment [183]. In this scenario, AT1R over-activity stimulates vasoconstriction and increases oxidative stress, inflammation, and susceptibility to ischemia. On the other hand, ACE2 overexpression and activity of the Ang (1-7)/MasR axis of RAS counteract the impact of AT1R activity, reducing both inducible NOS and the production of 


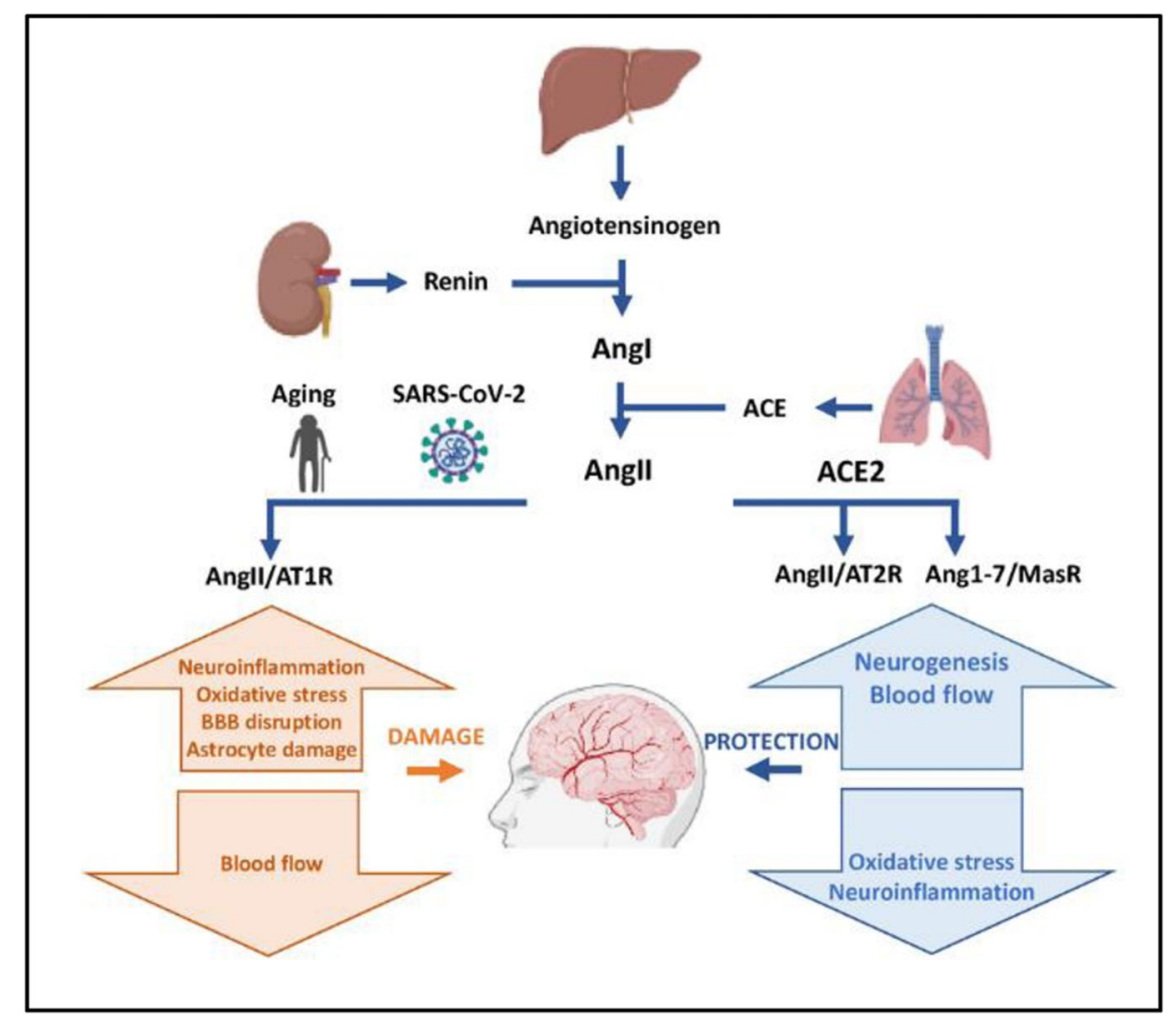

Fig. 3 RAS starts with the synthesis of protease renin in the kidney, which produces Ang-I from angiotensinogen in the liver. Ang-I is transformed in Ang-II by the action of ACE. Secondly, Ang (1-7) is produced by the action of ACE2 on Ang-II. RAS function is dependent on the balance of two opposing pathways. One formed by Ang-II, and the AT1R (inflammatory way), and the other comprises Ang (1-7) that intervenes in its actions by binding to Mas receptor and Ang-II IAT2R (anti-inflammatory way). The aging process unbalances

pro-inflammatory cytokines in the brain and promoting angiogenesis [184] (Fig. 3).

\section{CNS and post-acute sequelae of SARS-CoV-2 infection}

"Long COVID" syndrome includes multiple postacute sequelae of SARS-CoV-2 infection [185]. Numerous patients manifest prolonged multisystem compromise with significant disability [186]. After 6 months of SARS-CoV-2 infection, $76 \%$ of patients have at least one of the following symptoms: fatigue/ muscle weakness, difficulty sleeping, hair loss, anosmia, and mobility difficulties [187]. the RAS activation promoting abnormal levels of inflammation, oxidative stress with concomitant cell death. AT1R and Ang-II levels are upregulated during aging. In contrast to the counterbalanced components, AT2R and Ang (1-7)/Mas axis expression appeared to be decreed. This process could be exacerbated during SARS-CoV-2 infection and explain the accelerated neurodegenerative manifestation observed in aging phenotypes of COVID-19 patients

Neuropsychiatry and movement abnormalities are reported post-infection [188-190]. Among these, the lack of movement coordination, falls, gait shuffling, and confusion was detected in individuals testing negative for SARS-CoV-2 for several days [5, 191]. Consistent with these observed abnormalities, demyelinating lesions of the CNS driven by inflammation arising from activation of glial cells are also a sequela of COVID-19 [192, 193].

An inflammatory mechanism is considered the most plausible association between SARS-CoV-2 brain infection and neurological dysfunction. Encephalitis as the central neuroinflammatory sequelae SARS-CoV-2, especially in older adults, has been documented in neuroimaging, electrophysiological, and laboratory studies $[50,194]$. 
Although pathophysiological mechanisms of SARS-CoV-2 infection are still largely unknown, the neurological sequela observed after SARS-CoV-2 infection may suggest infection-driven damage to glial cells and neurons that express ACE2. Furthermore, the ACE2 substrate (Ang-II) is synthesized by ACE activity, which might be inhibited by endogenous serum albumin present in the blood and potentially many tissues, but not present in the CNS [195], and it is also tightly coordinated by genotype-dependent expression and secretion mechanisms [196]. Consequently, in the CNS location, a high ACE activity, and consequently of Ang-II level, is expectable, thus highlighting the role of ACE2 as its cellular down expression would result in a more severe dysregulation of local RAS.

Sequelae may also be due to the disruption of bidirectional interactions between the immune and nervous systems, which could lead to a pro-inflammatory, hypercoagulable, and hypoxemic state in the brain. Such an environment is expected to drive neurological syndromes including demyelinating and movement disorders, degenerative dementias, encephalopathies, and also neuropsychiatric and unusual cognitive disorders [197]. Consistent with this hypothesis, increased coagulopathy, vasculopathy, neuroinflammation, and immune dysregulation are expected to underlie the increase in the risk of stroke during the COVID-19 [198].

Damage to endothelial cells arising from direct SARS-CoV-2 infection likely drives COVID-19-associated coagulopathy that underlies specific forms of neurological dysfunction. Damaged endothelial cells produce excess nitric oxide, promoting platelet and leukocyte adhesion, followed by the migration of inflammatory cells [199]. Release of tissue factor (also known as coagulation factor III or tissue thromboplastin) after endothelial cell damage, especially in the brain, activates $\alpha$-thrombin, the final serine protease in the coagulation cascade [200]. The active thrombin disrupts BBB after cleaving protease-activated receptors known as PAR on endothelial cells thus gaining access to the CNS and impairing oxygen exchange. Once there, it can cleave to activate PARs on microglia/astrocytes for neuroinflammation and neurons to form neurofibrillary tangles [200]. Of note, microglial nodules formed after phagocytosis of hypoxic neurons were found in the cerebellum of COVID-19 patients
[201]. Consistent with this knowledge, COVID19 patients frequently present with microvascular ischemic and hemorrhagic parenchymal injury, microglial activation, and neuroinflammation [190, 199, 202]. Even mild respiratory SARS-CoV-2 infection without neuroinvasion may cause a multicellular dysregulation in the brain, including white matter microglial reactivity, abnormalities in neural precursor cell populations, reduction in hippocampal neurogenesis, depletion of myelinating oligodendrocytes, and myelin loss. Such anomalies are related to neurological symptoms, including impairment in attention, concentration, speed of information processing, and memory, as part of the longCOVID cognitive syndrome [203].

SARS-CoV-2 infection may directly impact mechanisms of disease in age-associated neurological disorders such as Alzheimer's disease (AD) and Parkinson's disease (PD). Vascular dysfunction plays a central role in AD and PD [204]. Expression of the ApoE4 allele - a major risk factor for $\mathrm{AD}$ and chronic traumatic encephalopathy - in glial cells is associated with more severe neurodegenerative symptoms observed in older COVID-19 patients [205]. Moreover, ACE is upregulated in the limbic regions of the brain of patients with $\mathrm{AD}$ [206].

In addition to the direct involvement of neurovascular damage arising from increased inflammation, some of the post-acute neurological sequelae associated with SARS-CoV-2 infection could be due to dysregulation of RAS. Hyperinflammation has been reported more frequently in older patients with SARS-CoV-2 infection and is related to dysregulated immune and RAS in older adults that may underlie the observed increased risk of mortality and postacute neurological sequelae in this demographic group [103].

The RAS plays a central role in the regulation of vascular function. Both the RAS and the vascular system are impacted by COVID-19 pathogenesis [207]. As discussed above, SARS-CoV-2 infection may exacerbate age-associated oxidative stress, which may compromise genome integrity in neurons and potentially other cells in the CNS, promoting neurodegenerative processes [208]. Studies that blocked the Ang-II receptor demonstrated that disruption of the blood-brain barrier is associated with RAS activation, dysfunction of the neurovascular unit, cognitive impairment, and dementia [209]. 
Although a strong association between SARSCoV-2 and peripheral neuromyopathy as GuillainBarré syndrome (GBS) is lacking, SARS-CoV-2 infection may be an occasional trigger for GBS. Previous studies showed that SARS-CoV-2-infected patients share neurological symptoms similar to those previously described in patients who experienced non-SARS-CoV-2 post-infection GBS [210, 211]. Moreover, peripheral neuropathy was most frequent among older adults [212].

Overall, a lower global cognitive performance score that is positively associated with severity of respiratory disease in COVID-19 patients suggests that brain injury could be due to reduced oxygen and subclinical neuroinflammation, both common in brain aging [213]. Taken together, this evidence may help explain the accelerated age-associated phenotypes observed in COVID-19 patients with neurodegenerative manifestations.

\section{Concluding remarks}

In addition to the respiratory tract, SARS-CoV-2 can also enter the CNS where it binds to cell receptors, including ACE2, expressed in several brain areas and both neuronal and non-neuronal cell types. The appearance or accelerated progression of neurodegenerative disease is manifested once the virus enters the CNS, promoting neuroinflammation, coagulopathies and hemorrhages, barrier dysfunction, and neuronal death. The varied range and severity of acute neurological COVID-19 syndromes as well as the consequences of sustained, viral-mediated neural dysregulation of peripheral systems may be a unique feature of SARS-CoV-2 infection. A disturbance of the bidirectional interactions of the nervous system and the RAS may accelerate aging through the generation of a pro-inflammatory state that can promote long-term neurological syndromes.

Author contribution Jorge Quarleri and Maria Victoria Delpino: Both have contributed equally to conceptualization, methodology, writing, review, and editing.

\section{Declarations}

Conflict of interest The authors declare no competing interests.

\section{References}

1. Walker PJ, Siddell SG, Lefkowitz EJ, Mushegian AR, Dempsey DM, Dutilh BE, Harrach B, Harrison RL, Hendrickson RC, Junglen S, Knowles NJ, Kropinski AM, Krupovic M, Kuhn JH, Nibert M, Rubino L, Sabanadzovic S, Simmonds P, Varsani A, Zerbini FM, Davison AJ. Changes to virus taxonomy and the International Code of Virus Classification and Nomenclature ratified by the International Committee on Taxonomy of Viruses (2019). Arch Virol. 2019;164:2417-29.

2. Rabi FA, Al Zoubi MS, Kasasbeh GA, Salameh DM, Al-Nasser AD. SARS-CoV-2 and Coronavirus Disease 2019: What We Know So Far. Pathogens. 2020;9(3):231.

3. Wiersinga WJ. Clinical characteristics of coronavirus disease 2019 in the Netherlands. Ned Tijdschr Geneeskd. 2020;164:D5021.

4. Zou X, Chen K, Zou J, Han P, Hao J, Han Z. Singlecell RNA-seq data analysis on the receptor ACE2 expression reveals the potential risk of different human organs vulnerable to 2019-nCoV infection. Front Med. 2020;14:185-92.

5. Mao L, Jin H, Wang M, Hu Y, Chen S, He Q, Chang J, Hong C, Zhou Y, Wang D, Miao X, Li Y, Hu B. Neurologic manifestations of hospitalized patients with coronavirus disease 2019 in Wuhan, China. JAMA Neurol. 2020;77:683-90.

6. Misra, S., Kolappa, K., Prasad, M., Radhakrishnan, D., Thakur, K.T., Solomon, T., Michael, B.D., Winkler, A.S., Beghi, E., Guekht, A., Pardo, C.A., Wood, G.K., HsiangYi Chou, S., Fink, E.L., Schmutzhard, E., Kheradmand, A., Hoo, F.K., Kumar, A., Das, A., Srivastava, A.K., Agarwal, A., Dua, T. and Prasad, K., 2021, Frequency of neurologic manifestations in COVID-19: a systematic review and meta-analysis. Neurology 9723 e2269-e2281

7. Nepal G, Rehrig JH, Shrestha GS, Shing YK, Yadav JK, Ojha R, Pokhrel G, Tu ZL, Huang DY. Neurological manifestations of COVID-19: a systematic review. Crit Care. 2020;24:421.

8. Moriguchi T, Harii N, Goto J, Harada D, Sugawara H, Takamino J, Ueno M, Sakata H, Kondo K, Myose N, Nakao A, Takeda M, Haro H, Inoue O, Suzuki-Inoue K, Kubokawa K, Ogihara S, Sasaki T, Kinouchi H, Kojin H, Ito M, Onishi H, Shimizu T, Sasaki Y, Enomoto N, Ishihara H, Furuya S, Yamamoto T, Shimada S. A first case of meningitis/encephalitis associated with SARS-Coronavirus-2. Int J Infect Dis. 2020;94:55-8.

9. Paniz-Mondolfi A, Bryce C, Grimes Z, Gordon RE, Reidy J, Lednicky J, Sordillo EM, Fowkes M. Central nervous system involvement by severe acute respiratory syndrome coronavirus-2 (SARS-CoV-2). J Med Virol. 2020;92:699-702.

10. Puelles VG, Lutgehetmann M, Lindenmeyer MT, Sperhake JP, Wong MN, Allweiss L, Chilla S, Heinemann A, Wanner N, Liu S, Braun F, Lu S, Pfefferle S, Schroder AS, Edler C, Gross O, Glatzel M, Wichmann D, Wiech T, Kluge S, Pueschel K, Aepfelbacher M, Huber TB. Multiorgan and renal tropism of SARSCoV-2. N Engl J Med. 2020;383:590-2. 
11. Solomon $\mathrm{IH}$, Normandin E, Bhattacharyya S, Mukerji SS, Keller K, Ali AS, Adams G, Hornick JL, Padera RF Jr, Sabeti P. Neuropathological features of COVID19. N Engl J Med. 2020;383:989-92.

12. Ellul MA, Benjamin L, Singh B, Lant S, Michael BD, Easton A, Kneen R, Defres S, Sejvar J, Solomon T. Neurological associations of COVID-19. Lancet Neurol. 2020;19:767-83.

13. Iadecola C, Anrather J, Kamel H. Effects of COVID-19 on the nervous system. Cell. 2020;183:16 27-e11.

14. Koralnik IJ, Tyler KL. COVID-19: a global threat to the nervous system. Ann Neurol. 2020;88:1-11.

15. Paterson RW, Brown RL, Benjamin L, Nortley R, Wiethoff S, Bharucha T, Jayaseelan DL, Kumar G, Raftopoulos RE, Zambreanu L, Vivekanandam V, Khoo A, Geraldes R, Chinthapalli K, Boyd E, Tuzlali H, Price G, Christofi G, Morrow J, McNamara P, McLoughlin B, Lim ST, Mehta PR, Levee V, Keddie S, Yong W, Trip SA, Foulkes AJM, Hotton G, Miller TD, Everitt AD, Carswell C, Davies NWS, Yoong M, Attwell D, Sreedharan J, Silber E, Schott JM, Chandratheva A, Perry RJ, Simister R, Checkley A, Longley N, Farmer SF, Carletti F, Houlihan C, Thom M, Lunn MP, Spillane J, Howard R, Vincent A, Werring DJ, Hoskote C, Jager HR, Manji H, Zandi MS. The emerging spectrum of COVID-19 neurology: clinical, radiological and laboratory findings. Brain. 2020;143:3104-20.

16. Patone, M., Handunnetthi, L., Saatci, D., Pan, J., Katikireddi, S.V., Razvi, S., Hunt, D., Mei, X.W., Dixon, S., Zaccardi, F., Khunti, K., Watkinson, P., Coupland, C.A.C., Doidge, J., Harrison, D.A., Ravanan, R., Sheikh, A., Robertson, C. and Hippisley-Cox, J., 2021, Neurological complications after first dose of COVID19 vaccines and SARS-CoV-2 infection. Nat Med 27 12 2144-2153

17. Spudich S, Nath A. Nervous system consequences of COVID-19. Science. 2022;375:267-9.

18. Choudhury A, Mukherjee S. In silico studies on the comparative characterization of the interactions of SARSCoV-2 spike glycoprotein with ACE-2 receptor homologs and human TLRs. J Med Virol. 2020;92:2105-13.

19. Jin Y, Yang H, Ji W, Wu W, Chen S, Zhang W, Duan G. Virology, epidemiology, pathogenesis, and control of COVID-19. Viruses. 2020;12(4):372.

20. Motayo BO, Oluwasemowo OO, Akinduti PA. Evolutionary dynamics and geographic dispersal of beta coronaviruses in African bats. PeerJ. 2020;8:e10434.

21. Onofrio L, Caraglia M, Facchini G, Margherita V, Placido S, Buonerba C. Toll-like receptors and COVID-19: a two-faced story with an exciting ending. Future Sci OA. 2020;6:FSO605.

22. Letko M, Marzi A, Munster V. Functional assessment of cell entry and receptor usage for SARS-CoV-2 and other lineage B betacoronaviruses. Nat Microbiol. 2020;5:562-9.

23. Hamming I, Timens W, Bulthuis ML, Lely AT, Navis $\mathrm{G}$, van Goor $\mathrm{H}$. Tissue distribution of ACE2 protein, the functional receptor for SARS coronavirus. A first step in understanding SARS pathogenesis. J Pathol. 2004;203:631-7.
24. Natoli S, Oliveira V, Calabresi P, Maia LF, Pisani A. Does SARS-Cov-2 invade the brain? Translational lessons from animal models. Eur J Neurol. 2020;27:1764-73.

25. Wrapp D, McLellan JS. The 3.1-angstrom cryo-electron microscopy structure of the porcine epidemic diarrhea virus spike protein in the prefusion conformation. $\mathrm{J}$ Virol. 2019;93(23):e00923 19.

26. Bailey AL, Diamond MS. A Crisp(r) New Perspective on SARS-CoV-2 Biology. Cell. 2021;184:15-7.

27. Zipeto D, Palmeira JDF, Arganaraz GA, Arganaraz ER. ACE2/ADAM17/TMPRSS2 Interplay may be the main risk factor for COVID-19. Front Immunol. 2020;11:576745.

28. Hoffmann M, Kleine-Weber H, Pohlmann S. A multibasic cleavage site in the spike protein of SARS-CoV-2 is essential for infection of human lung cells. Mol Cell. 2020;78:779-784 e775.

29. Cantuti-Castelvetri L, Ojha R, Pedro LD, Djannatian M, Franz J, Kuivanen S, van der Meer F, Kallio K, Kaya T, Anastasina M, Smura T, Levanov L, Szirovicza L, Tobi A, Kallio-Kokko H, Osterlund P, Joensuu M, Meunier FA, Butcher SJ, Winkler MS, Mollenhauer B, Helenius A, Gokce O, Teesalu T, Hepojoki J, Vapalahti O, Stadelmann C, Balistreri G, Simons M. Neuropilin-1 facilitates SARS-CoV-2 cell entry and infectivity. Science. 2020;370:856-60.

30. Masre SF, Jufri NF, Ibrahim FW, Abdul Raub SH. Classical and alternative receptors for SARS-CoV-2 therapeutic strategy. Rev Med Virol. 2020;31(5):e2207.

31. Radzikowska U, Ding M, Tan G, Zhakparov D, Peng Y, Wawrzyniak P, Wang M, Li S, Morita H, Altunbulakli C, Reiger M, Neumann AU, Lunjani N, Traidl-Hoffmann C, Nadeau KC, O'Mahony L, Akdis C, Sokolowska M. Distribution of ACE2, CD147, CD26, and other SARSCoV-2 associated molecules in tissues and immune cells in health and in asthma, COPD, obesity, hypertension, and COVID-19 risk factors. Allergy. 2020;75:2829-45.

32. Wang K, Chen W, Zhang Z, Deng Y, Lian JQ, Du P, Wei D, Zhang Y, Sun XX, Gong L, Yang X, He L, Zhang L, Yang Z, Geng JJ, Chen R, Zhang H, Wang B, Zhu YM, Nan G, Jiang JL, Li L, Wu J, Lin P, Huang W, Xie L, Zheng ZH, Zhang K, Miao JL, Cui HY, Huang M, Zhang J, Fu L, Yang XM, Zhao Z, Sun S, Gu H, Wang Z, Wang CF, Lu Y, Liu YY, Wang QY, Bian H, Zhu P, Chen ZN. CD147-spike protein is a novel route for SARS-CoV-2 infection to host cells. Signal Transduct Target Ther. 2020;5:283.

33. Balakumar P, Jagadeesh G. A century old renin-angiotensin system still grows with endless possibilities: AT1 receptor signaling cascades in cardiovascular physiopathology. Cell Signal. 2014;26:2147-60.

34. Cosarderelioglu C, Nidadavolu LS, George CJ, Oh ES, Bennett DA, Walston JD, Abadir PM. Brain renin-angiotensin system at the intersect of physical and cognitive frailty. Front Neurosci. 2020;14:586314.

35. Fujita T, Hirooka K, Nakamura T, Itano T, Nishiyama A, Nagai Y, Shiraga F. Neuroprotective effects of angiotensin II type 1 receptor (AT1-R) blocker via modulating AT1-R signaling and decreased extracellular glutamate levels. Invest Ophthalmol Vis Sci. 2012;53:4099-110. 
36. Tedesco A, Ally A. Angiotensin II type-2 (AT2) receptor antagonism alters cardiovascular responses to static exercise and simultaneously changes glutamate/GABA levels within the ventrolateral medulla. Neurosci Res. 2009;64:372-9.

37. Tsuda K. Renin-Angiotensin system and sympathetic neurotransmitter release in the central nervous system of hypertension. Int J Hypertens. 2012;2012:474870.

38. Grobe JL, Grobe CL, Beltz TG, Westphal SG, Morgan DA, Xu D, de Lange WJ, Li H, Sakai K, Thedens DR, Cassis LA, Rahmouni K, Mark AL, Johnson AK, Sigmund $\mathrm{CD}$. The brain renin-angiotensin system controls divergent efferent mechanisms to regulate fluid and energy balance. Cell Metab. 2010;12:431-42.

39. Nakagawa P, Gomez J, Grobe JL, Sigmund CD. The renin-angiotensin system in the central nervous system and its role in blood pressure regulation. Curr Hypertens Rep. 2020;22:7.

40. Kamo T, Akazawa H, Komuro I. Pleiotropic effects of angiotensin ii receptor signaling in cardiovascular homeostasis and aging. Int Heart J. 2015;56:249-54.

41. Benigni A, Corna D, Zoja C, Sonzogni A, Latini R, Salio M, Conti S, Rottoli D, Longaretti L, Cassis P, Morigi M, Coffman TM, Remuzzi G. Disruption of the Ang II type 1 receptor promotes longevity in mice. J Clin Invest. 2009;119:524-30.

42. Kamo T, Akazawa H, Suzuki JI, Komuro I. Roles of renin-angiotensin system and Wnt pathway in agingrelated phenotypes. Inflamm Regen. 2016;36:12.

43. Ahmad I, Rathore FA. Neurological manifestations and complications of COVID-19: a literature review. J Clin Neurosci. 2020;77:8-12.

44. Song, E., Zhang, C., Israelow, B., Lu-Culligan, A., Prado, A.V., Skriabine, S., Lu, P., Weizman, O.E., Liu, F., Dai, Y., Szigeti-Buck, K., Yasumoto, Y., Wang, G., Castaldi, C., Heltke, J., Ng, E., Wheeler, J., Alfajaro, M.M., Levavasseur, E., Fontes, B., Ravindra, N.G., Van Dijk, D., Mane, S., Gunel, M., Ring, A., Kazmi, S.A.J., Zhang, K., Wilen, C.B., Horvath, T.L., Plu, I., Haik, S., Thomas, J.L., Louvi, A., Farhadian, S.F., Huttner, A., Seilhean, D., Renier, N., Bilguvar, K. and Iwasaki, A., 2020, Neuroinvasion of SARS-CoV-2 in human and mouse brain. bioRxiv.

45. Nath A, Smith B. Neurological complications of COVID-19: from bridesmaid to bride. Arq Neuropsiquiatr. 2020;78:459-60.

46. Nath A, Smith B. Neurological issues during COVID-19: an overview. Neurosci Lett. 2021;742:135533.

47. Li YC, Bai WZ, Hashikawa T. The neuroinvasive potential of SARS-CoV2 may play a role in the respiratory failure of COVID-19 patients. J Med Virol. 2020;92:552-5.

48. Wu Y, Xu X, Chen Z, Duan J, Hashimoto K, Yang L, Liu C, Yang C. Nervous system involvement after infection with COVID-19 and other coronaviruses. Brain Behav Immun. 2020;87:18-22.

49. Benameur K, Agarwal A, Auld SC, Butters MP, Webster AS, Ozturk T, Howell JC, Bassit LC, Velasquez A, Schinazi RF, Mullins ME, Hu WT. Encephalopathy and encephalitis associated with cerebrospinal fluid cytokine alterations and coronavirus disease, Atlanta, Georgia, USA, 2020. Emerg Infect Dis. 2020;26:2016-21.
50. Garg RK, Paliwal VK, Gupta A. Encephalopathy in patients with COVID-19: a review. J Med Virol. 2021;93:206-22.

51. Parsons T, Banks S, Bae C, Gelber J, Alahmadi H, Tichauer M. COVID-19-associated acute disseminated encephalomyelitis (ADEM). J Neurol. 2020;267:2799-802.

52. Chen T, Wu D, Chen H, Yan W, Yang D, Chen G, Ma $\mathrm{K}$, Xu D, Yu H, Wang H, Wang T, Guo W, Chen J, Ding C, Zhang X, Huang J, Han M, Li S, Luo X, Zhao J, Ning Q. Clinical characteristics of 113 deceased patients with coronavirus disease 2019: retrospective study. BMJ. 2020;368:m1091.

53. Sweeney MD, Ayyadurai S, Zlokovic BV. Pericytes of the neurovascular unit: key functions and signaling pathways. Nat Neurosci. 2016;19:771-83.

54. Wang L, Sievert D, Clark AE, Lee S, Federman H, Gastfriend BD, Shusta EV, Palecek SP, Carlin AF, Gleeson JG. A human three-dimensional neuralperivascular 'assembloid' promotes astrocytic development and enables modeling of SARS-CoV-2 neuropathology. Nat Med. 2021;27:1600-6.

55. Wenzel J, Lampe J, Muller-Fielitz H, Schuster R, Zille M, Muller K, Krohn M, Korbelin J, Zhang L, Ozorhan U, Neve V, Wagner JUG, Bojkova D, Shumliakivska M, Jiang Y, Fahnrich A, Ott F, Sencio V, Robil C, Pfefferle S, Sauve F, Coelho CFF, Franz J, Spiecker F, Lembrich B, Binder S, Feller N, Konig P, Busch H, Collin L, Villasenor R, Johren O, Altmeppen HC, Pasparakis M, Dimmeler S, Cinatl J, Puschel K, Zelic M, Ofengeim D, Stadelmann C, Trottein F, Nogueiras R, Hilgenfeld R, Glatzel M, Prevot V, Schwaninger M. The SARS-CoV-2 main protease M(pro) causes microvascular brain pathology by cleaving NEMO in brain endothelial cells. Nat Neurosci. 2021;24:1522-33.

56. Koyuncu OO, Hogue IB, Enquist LW. Virus infections in the nervous system. Cell Host Microbe. 2013;13:379-93.

57. Suen WW, Prow NA, Hall RA, Bielefeldt-Ohmann H. Mechanism of West Nile virus neuroinvasion: a critical appraisal. Viruses. 2014;6:2796-825.

58. Constant O, Barthelemy J, Bollore K, Tuaillon E, Gosselet F, Chable-Bessia C, Merida P, Muriaux D, Van de Perre P, Salinas S, Simonin Y. SARS-CoV-2 poorly replicates in cells of the human blood-brain barrier without associated deleterious effects. Front Immunol. 2021;12:697329.

59. Chigr F, Merzouki M, Najimi M. Comment on "The neuroinvasive potential of SARS-CoV-2 may play a role in the respiratory failure of COVID-19 patients." $\mathrm{J}$ Med Virol. 2020;92:703-4.

60. Dantzer R. Neuroimmune Interactions: from the brain to the immune system and vice versa. Physiol Rev. 2018;98:477-504.

61. Swanson PA 2nd, McGavern DB. Viral diseases of the central nervous system. Curr Opin Virol. 2015;11:44-54.

62. Varga Z, Flammer AJ, Steiger P, Haberecker M, Andermatt R, Zinkernagel AS, Mehra MR, Schuepbach RA, Ruschitzka F, Moch H. Endothelial cell infection and endotheliitis in COVID-19. Lancet. 2020;395:1417-8. 
63. Tang Y, Liu J, Zhang D, Xu Z, Ji J, Wen C. Cytokine storm in COVID-19: the current evidence and treatment strategies. Front Immunol. 2020;11:1708.

64. Honigsbaum M. "An inexpressible dread": psychoses of influenza at fin-de-siecle. Lancet. 2013;381:988-9.

65. McCray PB Jr, Pewe L, Wohlford-Lenane C, Hickey M, Manzel L, Shi L, Netland J, Jia HP, Halabi C, Sigmund CD, Meyerholz DK, Kirby P, Look DC, Perlman S. Lethal infection of K18-hACE2 mice infected with severe acute respiratory syndrome coronavirus. J Virol. 2007;81:813-21.

66. Roe K, Kumar M, Lum S, Orillo B, Nerurkar VR, Verma S. West Nile virus-induced disruption of the blood-brain barrier in mice is characterized by the degradation of the junctional complex proteins and increase in multiple matrix metalloproteinases. J Gen Virol. 2012;93:1193-203.

67. Wohleb ES, McKim DB, Sheridan JF, Godbout JP. Monocyte trafficking to the brain with stress and inflammation: a novel axis of immune-to-brain communication that influences mood and behavior. Front Neurosci. 2014;8:447.

68. Chen G, Wu D, Guo W, Cao Y, Huang D, Wang H, Wang T, Zhang X, Chen H, Yu H, Zhang X, Zhang M, Wu S, Song J, Chen T, Han M, Li S, Luo X, Zhao J, Ning Q. Clinical and immunological features of severe and moderate coronavirus disease 2019. J Clin Invest. 2020;130:2620-9.

69. Desforges M, Le Coupanec A, Dubeau P, Bourgouin A, Lajoie L, Dube M, Talbot PJ. Human coronaviruses and other respiratory viruses: underestimated opportunistic pathogens of the central nervous system? Viruses. 2019;12(1):14.

70. Gu J, Gong E, Zhang B, Zheng J, Gao Z, Zhong Y, Zou W, Zhan J, Wang S, Xie Z, Zhuang H, Wu B, Zhong H, Shao H, Fang W, Gao D, Pei F, Li X, He Z, Xu D, Shi X, Anderson VM, Leong AS. Multiple organ infection and the pathogenesis of SARS. J Exp Med. 2005;202:415-24.

71. Jessen NA, Munk AS, Lundgaard I, Nedergaard M. The glymphatic system: a beginner's guide. Neurochem Res. 2015;40:2583-99.

72. Brinker T, Stopa E, Morrison J, Klinge P. A new look at cerebrospinal fluid circulation. Fluids Barriers CNS. 2014;11:10.

73. Desforges M, Le Coupanec A, Stodola JK, MeessenPinard M, Talbot PJ. Human coronaviruses: viral and cellular factors involved in neuroinvasiveness and neuropathogenesis. Virus Res. 2014;194:145-58.

74. Fenrich M, Mrdenovic S, Balog M, Tomic S, Zjalic M, Roncevic A, Mandic D, Debeljak Z, Heffer M. SARSCoV-2 dissemination through peripheral nerves explains multiple organ injury. Front Cell Neurosci. 2020;14:229.

75. Dube M, Le Coupanec A, Wong AHM, Rini JM, Desforges M, Talbot PJ. Axonal transport enables neuron-toneuron propagation of human coronavirus OC43. J Virol. 2018;92(17):e00404-18.

76. Zubair AS, McAlpine LS, Gardin T, Farhadian S, Kuruvilla DE, Spudich S. Neuropathogenesis and neurologic manifestations of the coronaviruses in the age of coronavirus disease 2019: a review. JAMA Neurol. 2020;77:1018-27.
77. Brann DH, Tsukahara T, Weinreb C, Lipovsek M, Van den Berge K, Gong B, Chance R, Macaulay IC, Chou HJ, Fletcher RB, Das D, Street K, de Bezieux HR, Choi YG, Risso D, Dudoit S, Purdom E, Mill J, Hachem RA, Matsunami H, Logan DW, Goldstein BJ, Grubb MS, Ngai J, Datta SR. Non-neuronal expression of SARS-CoV-2 entry genes in the olfactory system suggests mechanisms underlying COVID-19-associated anosmia. Sci Adv. 2020;6(31):eabc5801.

78. Politi LS, Salsano E, Grimaldi M. Magnetic resonance imaging alteration of the brain in a patient with coronavirus disease 2019 (COVID-19) and anosmia. JAMA Neurol. 2020;77:1028-9.

79. Aghagoli G, Gallo Marin B, Katchur NJ, Chaves-Sell F, Asaad WF, Murphy SA. Neurological involvement in COVID-19 and potential mechanisms: a review. Neurocrit Care. 2021;34:1062-71.

80. Adhikari SP, Meng S, Wu YJ, Mao YP, Ye RX, Wang QZ, Sun C, Sylvia S, Rozelle S, Raat H, Zhou H. Epidemiology, causes, clinical manifestation and diagnosis, prevention and control of coronavirus disease (COVID19) during the early outbreak period: a scoping review. Infect Dis Poverty. 2020;9:29.

81. Kabir MT, Uddin MS, Hossain MF, Abdulhakim JA, Alam MA, Ashraf GM, Bungau SG, Bin-Jumah MN, Abdel-Daim MM, Aleya L. nCOVID-19 Pandemic: From molecular pathogenesis to potential investigational therapeutics. Front Cell Dev Biol. 2020;8:616.

82. Qian X, Ren R, Wang Y, Guo Y, Fang J, Wu ZD, Liu PL, Han TR, Members of Steering Committee, S.o.G.H.C.P.M.A.,. Fighting against the common enemy of COVID-19: a practice of building a community with a shared future for mankind. Infect Dis Poverty. 2020;9:34.

83. Doobay MF, Talman LS, Obr TD, Tian X, Davisson RL, Lazartigues E. Differential expression of neuronal ACE2 in transgenic mice with overexpression of the brain renin-angiotensin system. Am J Physiol Regul Integr Comp Physiol. 2007;292:R373-381.

84. Huang C, Wang Y, Li X, Ren L, Zhao J, Hu Y, Zhang L, Fan G, Xu J, Gu X, Cheng Z, Yu T, Xia J, Wei Y, Wu W, Xie X, Yin W, Li H, Liu M, Xiao Y, Gao H, Guo L, Xie J, Wang G, Jiang R, Gao Z, Jin Q, Wang J, Cao B. Clinical features of patients infected with 2019 novel coronavirus in Wuhan, China. Lancet. 2020;395:497-506.

85. Tay MZ, Poh CM, Renia L, MacAry PA, Ng LFP. The trinity of COVID-19: immunity, inflammation and intervention. Nat Rev Immunol. 2020;20:363-74.

86. Zhou F, Yu T, Du R, Fan G, Liu Y, Liu Z, Xiang J, Wang Y, Song B, Gu X, Guan L, Wei Y, Li H, Wu X, Xu J, Tu S, Zhang Y, Chen H, Cao B. Clinical course and risk factors for mortality of adult inpatients with COVID-19 in Wuhan, China: a retrospective cohort study. Lancet. 2020;395:1054-62.

87. Xia H, Lazartigues E. Angiotensin-converting enzyme 2: central regulator for cardiovascular function. Curr Hypertens Rep. 2010;12:170-5.

88. Born J, Lange T, Kern W, McGregor GP, Bickel U, Fehm HL. Sniffing neuropeptides: a transnasal approach to the human brain. Nat Neurosci. 2002;5:514-6.

89. Dhuria SV, Hanson LR, Frey WH 2nd. Intranasal delivery to the central nervous system: mechanisms 
and experimental considerations. J Pharm Sci. 2010;99:1654-73.

90. Benarroch EE. Circumventricular organs: receptive and homeostatic functions and clinical implications. Neurology. 2011;77:1198-204.

91. Ganten D, Minnich JL, Granger P, Hayduk K, Brecht HM, Barbeau A, Boucher R, Genest J. Angiotensinforming enzyme in brain tissue. Science. 1971;173:64-5.

92. Ferrario CM, Ahmad S, Joyner J, Varagic J. Advances in the renin angiotensin system focus on angiotensin-converting enzyme 2 and angiotensin-(1-7). Adv Pharmacol. 2010;59:197-233.

93. Ferreira AJ, Santos RA, Bradford CN, Mecca AP, Sumners C, Katovich MJ, Raizada MK. Therapeutic implications of the vasoprotective axis of the renin-angiotensin system in cardiovascular diseases. Hypertension. 2010;55:207-13.

94. Re RN. Role of intracellular angiotensin II. Am J Physiol Heart Circ Physiol. 2018;314:H766-71.

95. Lee-Kirsch MA, Gaudet F, Cardoso MC, Lindpaintner $\mathrm{K}$. Distinct renin isoforms generated by tissue-specific transcription initiation and alternative splicing. Circ Res. 1999;84:240-6.

96. Sinn PL, Sigmund CD. Identification of three human renin mRNA isoforms from alternative tissue-specific transcriptional initiation. Physiol Genomics. 2000;3:25-31.

97. Peters J, Wanka H, Peters B, Hoffmann S. A renin transcript lacking exon 1 encodes for a non-secretory intracellular renin that increases aldosterone production in transgenic rats. J Cell Mol Med. 2008;12:1229-37.

98. Grobe JL, Xu D, Sigmund CD. An intracellular reninangiotensin system in neurons: fact, hypothesis, or fantasy. Physiology (Bethesda). 2008;23:187-93.

99. von Bohlen und Halbach, O. and Albrecht, D.,. The CNS renin-angiotensin system. Cell Tissue Res. 2006;326:599-616.

100. Tufan A, Avanoglu Guler A, Matucci-Cerinic M. COVID-19, immune system response, hyperinflammation and repurposing antirheumatic drugs. Turk J Med Sci. 2020;50:620-32.

101. Brasier AR, Jamaluddin M, Han Y, Patterson C, Runge MS. Angiotensin II induces gene transcription through cell-type-dependent effects on the nuclear factor-kappaB (NF-kappaB) transcription factor. Mol Cell Biochem. 2000;212:155-69.

102. Lukiw WJ, Pogue A, Hill JM. SARS-CoV-2 infectivity and neurological targets in the brain. Cell Mol Neurobiol. 2020;421:217-24.

103. Saghazadeh A, Rezaei N. Immune-epidemiological parameters of the novel coronavirus - a perspective. Expert Rev Clin Immunol. 2020;16:465-70.

104. Butler MJ, Barrientos RM. The impact of nutrition on COVID-19 susceptibility and long-term consequences. Brain Behav Immun. 2020;87:53-4.

105. Linz W, Wohlfart P, Schoelkens BA, Becker RH, Malinski T, Wiemer G. Late treatment with ramipril increases survival in old spontaneously hypertensive rats. Hypertension. 1999;34:291-5.

106. Zhang Y, Lu J, Shi J, Lin X, Dong J, Zhang S, Liu Y, Tong Q. Central administration of angiotensin-(1-7) stimulates nitric oxide release and upregulates the endothelial nitric oxide synthase expression following focal cerebral ischemia/reperfusion in rats. Neuropeptides. 2008;42:593-600.

107. Jiang MH, Kaku T, Hada J, Hayashi Y. Different effects of eNOS and nNOS inhibition on transient forebrain ischemia. Brain Res. 2002;946:139-47.

108. Salom JB, Orti M, Centeno JM, Torregrosa G, Alborch E. Reduction of infarct size by the NO donors sodium nitroprusside and spermine/NO after transient focal cerebral ischemia in rats. Brain Res. 2000;865:149-56.

109. Jiang T, Gao L, Guo J, Lu J, Wang Y, Zhang Y. Suppressing inflammation by inhibiting the NF-kappaB pathway contributes to the neuroprotective effect of angiotensin-(1-7) in rats with permanent cerebral ischaemia. Br J Pharmacol. 2012;167:1520-32.

110. Mecca AP, Regenhardt RW, O'Connor TE, Joseph JP, Raizada MK, Katovich MJ, Sumners C. Cerebroprotection by angiotensin-(1-7) in endothelin-1-induced ischaemic stroke. Exp Physiol. 2011;96:1084-96.

111. Susswein AJ, Katzoff A, Miller N, Hurwitz I. Nitric oxide and memory. Neuroscientist. 2004;10:153-62.

112. Calabrese V, Mancuso C, Calvani M, Rizzarelli E, Butterfield DA, Stella AM. Nitric oxide in the central nervous system: neuroprotection versus neurotoxicity. Nat Rev Neurosci. 2007;8:766-75.

113. Annweiler C, Bourgeais A, Faucon E, Cao Z, Wu Y, Sabatier JM. Neurological, cognitive, and behavioral disorders during COVID-19: the nitric oxide track. J Am Geriatr Soc. 2020;68:1922-3.

114. Feng Y, Xia H, Santos RA, Speth R, Lazartigues E. Angiotensin-converting enzyme 2: a new target for neurogenic hypertension. Exp Physiol. 2010;95:601-6.

115. Sriramula S, Cardinale JP, Lazartigues E, Francis J. ACE2 overexpression in the paraventricular nucleus attenuates angiotensin II-induced hypertension. Cardiovasc Res. 2011;92:401-8.

116. Xia H, Suda S, Bindom S, Feng Y, Gurley SB, Seth D, Navar LG, Lazartigues E. ACE2-mediated reduction of oxidative stress in the central nervous system is associated with improvement of autonomic function. PLoS One. 2011;6:e22682.

117. Fagyas M, Kertesz A, Siket IM, Banhegyi V, Kracsko B, Szegedi A, Szokol M, Vajda G, Racz I, Gulyas H, Szkibak N, Racz V, Csanadi Z, Papp Z, Toth A, Sipka $S$. Level of the SARS-CoV-2 receptor ACE2 activity is highly elevated in old-aged patients with aortic stenosis: implications for ACE2 as a biomarker for the severity of COVID-19. Geroscience. 2021;43:19-29.

118. Uri K, Fagyas M, Kertesz A, Borbely A, Jenei C, Bene O, Csanadi Z, Paulus WJ, Edes I, Papp Z, Toth A, Lizanecz E. Circulating ACE2 activity correlates with cardiovascular disease development. J Renin Angiotensin Aldosterone Syst. 2016;17(4):1470320316668435.

119. Fagyas M, Banhegyi V, Uri K, Enyedi A, Lizanecz E, Manyine IS, Martha L, Fulop GA, Radovits T, Polos M, Merkely B, Kovacs A, Szilvassy Z, Ungvari Z, Edes I, Csanadi Z, Boczan J, Takacs I, Szabo G, Balla J, Balla G, Seferovic P, Papp Z, Toth A. Changes in the SARSCoV-2 cellular receptor ACE2 levels in cardiovascular 
patients: a potential biomarker for the stratification of COVID-19 patients. Geroscience. 2021;43:2289-304.

120. Wallentin L, Lindback J, Eriksson N, Hijazi Z, Eikelboom JW, Ezekowitz MD, Granger CB, Lopes RD, Yusuf S, Oldgren J, Siegbahn A. Angiotensin-converting enzyme 2 (ACE2) levels in relation to risk factors for COVID-19 in two large cohorts of patients with atrial fibrillation. Eur Heart J. 2020;41:4037-46.

121. Montanari M, Canonico B, Nordi E, Vandini D, Barocci S, Benedetti S, Carlotti E, Zamai L. Which ones, when and why should renin-angiotensin system inhibitors work against COVID-19? Adv Biol Regul. 2021;81:100820.

122. AlGhatrif M, Tanaka T, Moore AZ, Bandinelli S, Lakatta EG, Ferrucci L. Age-associated difference in circulating ACE2, the gateway for SARS-COV-2, in humans: results from the InCHIANTI study. Geroscience. 2021;43:619-27.

123. Fagyas M, Fejes Z, Suto R, Nagy Z, Szekely B, Pocsi M, Ivady G, Biro E, Beko G, Nagy A, Kerekes G, Szentkereszty Z, Papp Z, Toth A, Kappelmayer J, Nagy B Jr. Circulating ACE2 activity predicts mortality and disease severity in hospitalized COVID-19 patients. Int J Infect Dis. 2022;115:8-16.

124. Joshi S, Chittimalli K, Jahan J, Vasam G, Jarajapu YP. ACE2/ACE imbalance and impaired vasoreparative functions of stem/progenitor cells in aging. Geroscience. 2021;43:1423-36.

125. Akin S, Schriek P, van Nieuwkoop C, Neuman RI, Meynaar I, van Helden EJ, Bouazzaoui HE, Baak R, Veuger M, Mairuhu R, van den Berg L, van Driel V, Visser LE, de Jonge E, Garrelds IM, Duynstee J, van Rooden JK, Ludikhuize J, Verdonk K, Caliskan K, Jansen T, van Schaik RHN, Danser AHJ. A low aldosterone/renin ratio and high soluble ACE2 associate with COVID-19 severity. J Hypertens. 2021;40(3):606-14.

126. Kaur G, Yogeswaran S, Muthumalage T, Rahman I. Persistently increased systemic ACE2 activity is associated with an increased inflammatory response in smokers with COVID-19. Front Physiol. 2021;12:653045.

127. Kragstrup TW, Singh HS, Grundberg I, Nielsen AL, Rivellese F, Mehta A, Goldberg MB, Filbin MR, Qvist P, Bibby BM. Plasma ACE2 predicts outcome of COVID-19 in hospitalized patients. PLoS One. 2021;16:e0252799.

128. Nagy B Jr, Fejes Z, Szentkereszty Z, Suto R, Varkonyi I, Ajzner E, Kappelmayer J, Papp Z, Toth A, Fagyas M. A dramatic rise in serum ACE2 activity in a critically ill COVID-19 patient. Int J Infect Dis. 2021;103:412-4.

129. Patel SK, Juno JA, Lee WS, Wragg KM, Hogarth PM, Kent SJ, Burrell LM. Plasma ACE2 activity is persistently elevated following SARS-CoV-2 infection: implications for COVID-19 pathogenesis and consequences. Eur Respir J. 2021;57(5):2003730.

130. Reindl-Schwaighofer R, Hodlmoser S, Eskandary F, Poglitsch M, Bonderman D, Strassl R, Aberle JH, Oberbauer R, Zoufaly A, Hecking M. ACE2 elevation in severe COVID-19. Am J Respir Crit Care Med. 2021;203:1191-6.

131. van Lier D, Kox M, Santos K, van der Hoeven H, Pillay J, Pickkers P. Increased blood angiotensin converting enzyme 2 activity in critically ill COVID-19 patients. ERJ Open Res. 2021;7(1):00848-2020.

132. Kintscher U, Slagman A, Domenig O, Rohle R, Konietschke F, Poglitsch M, Mockel M. Plasma angiotensin peptide profiling and ace (angiotensin-converting enzyme)-2 activity in COVID-19 patients treated with pharmacological blockers of the renin-angiotensin system. Hypertension. 2020;76:e34-6.

133. Rieder M, Wirth L, Pollmeier L, Jeserich M, Goller I, Baldus N, Schmid B, Busch HJ, Hofmann M, Kern W, Bode C, Duerschmied D, Lother A. Serum ACE2, angiotensin ii, and aldosterone levels are unchanged in patients with COVID-19. Am J Hypertens. 2021;34:278-81.

134. Rojas M, Acosta-Ampudia Y, Monsalve DM, RamirezSantana C, Anaya JM. How important is the assessment of soluble ACE-2 in COVID-19? Am J Hypertens. 2021;34:296-7.

135. Xu J, Sriramula S, Xia H, Moreno-Walton L, Culicchia F, Domenig O, Poglitsch M, Lazartigues E. Clinical relevance and role of neuronal AT1 receptors in ADAM17mediated ACE2 shedding in neurogenic hypertension. Circ Res. 2017;121:43-55.

136. Glowacka I, Bertram S, Herzog P, Pfefferle S, Steffen I, Muench MO, Simmons G, Hofmann H, Kuri T, Weber F, Eichler J, Drosten C, Pohlmann S. Differential downregulation of ACE2 by the spike proteins of severe acute respiratory syndrome coronavirus and human coronavirus NL63. J Virol. 2010;84:1198-205.

137. Haga S, Yamamoto N, Nakai-Murakami C, Osawa Y, Tokunaga K, Sata T, Yamamoto N, Sasazuki T, Ishizaka Y. Modulation of TNF-alpha-converting enzyme by the spike protein of SARS-CoV and ACE2 induces TNFalpha production and facilitates viral entry. Proc Natl Acad Sci U S A. 2008;105:7809-14.

138. Kuba K, Imai Y, Penninger JM. Angiotensin-converting enzyme 2 in lung diseases. Curr Opin Pharmacol. 2006;6:271-6.

139. Oudit GY, Imai Y, Kuba K, Scholey JW, Penninger JM. The role of ACE2 in pulmonary diseases-relevance for the nephrologist. Nephrol Dial Transplant. 2009;24:1362-5.

140. Zhang C, Zhao YX, Zhang YH, Zhu L, Deng BP, Zhou ZL, Li SY, Lu XT, Song LL, Lei XM, Tang WB, Wang N, Pan CM, Song HD, Liu CX, Dong B, Zhang Y, Cao Y. Angiotensin-converting enzyme 2 attenuates atherosclerotic lesions by targeting vascular cells. Proc Natl Acad Sci U S A. 2010;107:15886-91.

141. Fraga-Silva RA, Sorg BS, Wankhede M, Dedeugd C, Jun JY, Baker MB, Li Y, Castellano RK, Katovich MJ, Raizada MK, Ferreira AJ. ACE2 activation promotes antithrombotic activity. Mol Med. 2010;16:210-5.

142. Becker LK, Etelvino GM, Walther T, Santos RA, Campagnole-Santos MJ. Immunofluorescence localization of the receptor Mas in cardiovascular-related areas of the rat brain. Am J Physiol Heart Circ Physiol. 2007;293:H1416-1424.

143. Costa-Besada MA, Valenzuela R, Garrido-Gil P, VillarCheda B, Parga JA, Lanciego JL, Labandeira-Garcia JL. Paracrine and intracrine angiotensin 1-7/Mas receptor axis in the substantia nigra of rodents, monkeys, and humans. Mol Neurobiol. 2018;55:5847-67. 
144. Freund M, Walther T, von Bohlen und Halbach, O.,. Immunohistochemical localization of the angiotensin-(1-7) receptor Mas in the murine forebrain. Cell Tissue Res. 2012;348:29-35.

145. Lazaroni TL, Raslan AC, Fontes WR, de Oliveira ML, Bader M, Alenina N, Moraes MF, Dos Santos RA, Pereira GS. Angiotensin-(1-7)/Mas axis integrity is required for the expression of object recognition memory. Neurobiol Learn Mem. 2012;97:113-23.

146. Jiang T, Gao L, Lu J, Zhang YD. ACE2-Ang-(1-7)Mas axis in brain: a potential target for prevention and treatment of ischemic stroke. Curr Neuropharmacol. 2013;11:209-17.

147. Pena Silva RA, Chu Y, Miller JD, Mitchell IJ, Penninger JM, Faraci FM, Heistad DD. Impact of ACE2 deficiency and oxidative stress on cerebrovascular function with aging. Stroke. 2012;43:3358-63.

148. Farag E, Sessler DI, Ebrahim Z, Kurz A, Morgan J, Ahuja S, Maheshwari K, John Doyle D. The renin angiotensin system and the brain: New developments. J Clin Neurosci. 2017;46:1-8.

149. Wright JW, Kawas LH, Harding JW. A role for the brain RAS in Alzheimer's and Parkinson's diseases. Front Endocrinol (Lausanne). 2013;4:158.

150. Ho JK, Nation DA. Cognitive benefits of angiotensin IV and angiotensin-(1-7): a systematic review of experimental studies. Neurosci Biobehav Rev. 2018;92:209-25.

151. Jiang T, Yu JT, Zhu XC, Zhang QQ, Tan MS, Cao L, Wang HF, Lu J, Gao Q, Zhang YD, Tan L. Angiotensin-(1-7) induces cerebral ischaemic tolerance by promoting brain angiogenesis in a Mas/eNOS-dependent pathway. Br J Pharmacol. 2014; 171:4222-32.

152. Wang XL, Iwanami J, Min LJ, Tsukuda K, Nakaoka H, Bai HY, Shan BS, Kan-No H, Kukida M, Chisaka T, Yamauchi T, Higaki A, Mogi M, Horiuchi M. Deficiency of angiotensin-converting enzyme 2 causes deterioration of cognitive function. NPJ Aging Mech Dis. 2016;2:16024.

153. Wang L, de Kloet AD, Pati D, Hiller H, Smith JA, Pioquinto DJ, Ludin JA, Oh SP, Katovich MJ, Frazier CJ, Raizada MK, Krause EG. Increasing brain angiotensin converting enzyme 2 activity decreases anxiety-like behavior in male mice by activating central Mas receptors. Neuropharmacology. 2016;105:114-23.

154. Kangussu LM, Almeida-Santos AF, Moreira FA, Fontes MAP, Santos RAS, Aguiar DC, Campagnole-Santos MJ. Reduced anxiety-like behavior in transgenic rats with chronically overproduction of angiotensin-(1-7): role of the Mas receptor. Behav Brain Res. 2017;331:193-8.

155. Moura Santos D, Ribeiro Marins F, Limborco-Filho M, de Oliveira ML, Hamamoto D, Xavier CH, Moreira FA, Santos RA, Campagnole-Santos MJ, Peliky Fontes MA. Chronic overexpression of angiotensin-(1-7) in rats reduces cardiac reactivity to acute stress and dampens anxious behavior. Stress. 2017;20:189-96.

156. Walther T, Balschun D, Voigt JP, Fink H, Zuschratter W, Birchmeier C, Ganten D, Bader M. Sustained long term potentiation and anxiety in mice lacking the Mas protooncogene. J Biol Chem. 1998;273:11867-73.

157. Wang LA, de Kloet AD, Smeltzer MD, Cahill KM, Hiller H, Bruce EB, Pioquinto DJ, Ludin JA, Katovich
MJ, Raizada MK, Krause EG. Coupling corticotropinreleasing-hormone and angiotensin converting enzyme 2 dampens stress responsiveness in male mice. Neuropharmacology. 2018;133:85-93.

158. Raony I, de Figueiredo CS, Pandolfo P, Giestal-deAraujo E, Oliveira-Silva Bomfim P, Savino W. PsychoNeuroendocrine-Immune Interactions in COVID-19: potential Impacts on Mental Health. Front Immunol. 2020;11:1170.

159. Wincewicz D, Braszko JJ. Telmisartan attenuates cognitive impairment caused by chronic stress in rats. Pharmacol Rep. 2014;66:436-41.

160. Raasch W, Wittmershaus C, Dendorfer A, Voges I, Pahlke F, Dodt C, Dominiak P, Johren O. Angiotensin II inhibition reduces stress sensitivity of hypothalamopituitary-adrenal axis in spontaneously hypertensive rats. Endocrinology. 2006;147:3539-46.

161. Rocha NP, Scalzo PL, Barbosa IG, de Campos-Carli SM, Tavares LD, de Souza MS, Christo PP, Reis HJ, Simoes ESAC, Teixeira AL. Peripheral levels of angiotensins are associated with depressive symptoms in Parkinson's disease. J Neurol Sci. 2016;368:235-9.

162. Jiang T, Gao L, Zhu XC, Yu JT, Shi JQ, Tan MS, Lu J, Tan L, Zhang YD. Angiotensin-(1-7) inhibits autophagy in the brain of spontaneously hypertensive rats. Pharmacol Res. 2013;71:61-8.

163. Zheng J, Li G, Chen S, Bihl J, Buck J, Zhu Y, Xia H, Lazartigues E, Chen Y, Olson JE. Activation of the ACE2/Ang-(1-7)/Mas pathway reduces oxygen-glucose deprivation-induced tissue swelling, ROS production, and cell death in mouse brain with angiotensin II overproduction. Neuroscience. 2014;273:39-51.

164. Kunieda T, Minamino T, Nishi J, Tateno K, Oyama T, Katsuno T, Miyauchi H, Orimo M, Okada S, Takamura M, Nagai T, Kaneko S, Komuro I. Angiotensin II induces premature senescence of vascular smooth muscle cells and accelerates the development of atherosclerosis via a p21-dependent pathway. Circulation. 2006;114:953-60.

165. Tsai IC, Pan ZC, Cheng HP, Liu CH, Lin BT, Jiang MJ. Reactive oxygen species derived from NADPH oxidase 1 and mitochondria mediate angiotensin II-induced smooth muscle cell senescence. J Mol Cell Cardiol. 2016;98:18-27.

166. Benigni A, Orisio S, Noris M, Iatropoulos P, Castaldi D, Kamide K, Rakugi H, Arai Y, Todeschini M, Ogliari G, Imai E, Gondo Y, Hirose N, Mari D, Remuzzi G. Variations of the angiotensin II type 1 receptor gene are associated with extreme human longevity. Age (Dordr). 2013;35:993-1005.

167. Abadir PM. The frail renin-angiotensin system. Clin Geriatr Med. 2011;27:53-65.

168. Abadir PM, Foster DB, Crow M, Cooke CA, Rucker JJ, Jain A, Smith BJ, Burks TN, Cohn RD, Fedarko NS, Carey RM, O'Rourke B, Walston JD. Identification and characterization of a functional mitochondrial angiotensin system. Proc Natl Acad Sci U S A. 2011;108:14849-54.

169. Gwathmey TM, Pendergrass KD, Reid SD, Rose JC, Diz DI, Chappell MC. Angiotensin-(1-7)-angiotensin-converting enzyme 2 attenuates reactive 
oxygen species formation to angiotensin II within the cell nucleus. Hypertension. 2010;55:166-71.

170. Millan MA, Jacobowitz DM, Aguilera G, Catt KJ. Differential distribution of AT1 and AT2 angiotensin II receptor subtypes in the rat brain during development. Proc Natl Acad Sci U S A. 1991;88:11440-4.

171. Carey RM, Siragy HM. Newly recognized components of the renin-angiotensin system: potential roles in cardiovascular and renal regulation. Endocr Rev. 2003;24:261-71.

172. Rodriguez-Perez AI, Garrido-Gil P, Pedrosa MA, Garcia-Garrote M, Valenzuela R, Navarro G, Franco R, Labandeira-Garcia JL. Angiotensin type 2 receptors: role in aging and neuroinflammation in the substantia nigra. Brain Behav Immun. 2020;87:256-71.

173. Villar-Cheda B, Rodriguez-Pallares J, Valenzuela R, Munoz A, Guerra MJ, Baltatu OC, Labandeira-Garcia JL. Nigral and striatal regulation of angiotensin receptor expression by dopamine and angiotensin in rodents: implications for progression of Parkinson's disease. Eur J Neurosci. 2010;32:1695-706.

174. Trifunovic A, Larsson NG. Mitochondrial dysfunction as a cause of ageing. J Intern Med. 2008;263:167-78.

175. Abadir PM, Walston JD, Carey RM. Subcellular characteristics of functional intracellular renin-angiotensin systems. Peptides. 2012;38:437-45.

176. Vajapey R, Rini D, Walston J, Abadir P. The impact of age-related dysregulation of the angiotensin system on mitochondrial redox balance. Front Physiol. 2014;5:439.

177. Feng X, Wang L, Li Y. Change of telomere length in angiotensin II-induced human glomerular mesangial cell senescence and the protective role of losartan. Mol Med Rep. 2011;4:255-60.

178. Diaz-Ruiz C, Villar-Cheda B, Dominguez-Meijide A, Garrido-Gil P, Guerra MJ, Labandeira-Garcia JL. Aging-related overactivity of the angiotensin/AT1 axis decreases sirtuin 3 levels in the substantia nigra, which induces vulnerability to oxidative stress and neurodegeneration. J Gerontol A Biol Sci Med Sci. 2020;75:416-24.

179. Valdez LB, Zaobornyj T, Alvarez S, Bustamante J, Costa LE, Boveris A. Heart mitochondrial nitric oxide synthase. Effects of hypoxia and aging. Mol Aspects Med. 2004;25:49-59.

180. Labandeira-Garcia JL, Rodriguez-Perez AI, Garrido-Gil P, Rodriguez-Pallares J, Lanciego JL, Guerra MJ. Brain renin-angiotensin system and microglial polarization: implications for aging and neurodegeneration. Front Aging Neurosci. 2017;9:129.

181. Lu J, Wu L, Jiang T, Wang Y, Zhao H, Gao Q, Pan Y, Tian Y, Zhang Y. Angiotensin AT2 receptor stimulation inhibits activation of NADPH oxidase and ameliorates oxidative stress in rotenone model of Parkinson's disease in CATH.a cells. Neurotoxicol Teratol. 2015;47:16-24.

182. Arvanitakis Z, Capuano AW, Leurgans SE, Bennett DA, Schneider JA. Relation of cerebral vessel disease to Alzheimer's disease dementia and cognitive function in elderly people: a cross-sectional study. Lancet Neurol. 2016;15:934-43.

183. Ahmed HA, Ishrat T, Pillai B, Bunting KM, Vazdarjanova A, Waller JL, Ergul A, Fagan SC. Angiotensin receptor (AT2R) agonist C21 prevents cognitive decline after permanent stroke in aged animals-a randomized double- blind pre-clinical study. Behav Brain Res. 2019;359:560-9.

184. Arroja MM, Reid E, McCabe C. Therapeutic potential of the renin angiotensin system in ischaemic stroke. Exp Transl Stroke Med. 2016;8:8.

185. Boldrini M, Canoll PD, Klein RS. How COVID-19 affects the brain. JAMA Psychiat. 2021;78:682-3.

186. Davis HE, Geornaras I, Lindstrom V, Chaparro JM, Nair MN, Delmore RJ, Engle TE, Belk KE, Prenni JE. Effects of differing withdrawal times from ractopamine hydrochloride on residue concentrations of beef muscle, adipose tissue, rendered tallow, and large intestine. PLoS One. 2020;15:e0242673.

187. Huang C, Huang L, Wang Y, Li X, Ren L, Gu X, Kang L, Guo L, Liu M, Zhou X, Luo J, Huang Z, Tu S, Zhao Y, Chen L, Xu D, Li Y, Li C, Peng L, Li Y, Xie W, Cui D, Shang L, Fan G, Xu J, Wang G, Wang Y, Zhong J, Wang C, Wang J, Zhang D, Cao B. 6-month consequences of COVID-19 in patients discharged from hospital: a cohort study. Lancet. 2021;397:220-32.

188. Nolen LT, Mukerji SS, Mejia NI. Post-acute neurological consequences of COVID-19: an unequal burden. Nat Med. 2022;28(1):20-3.

189. Poyiadji N, Shahin G, Noujaim D, Stone M, Patel S, Griffith B. COVID-19-associated acute hemorrhagic necrotizing encephalopathy: imaging features. Radiology. 2020;296:E119-20.

190. Thakur, K.T., Miller, E.H., Glendinning, M.D., AlDalahmah, O., Banu, M.A., Boehme, A.K., Boubour, A.L., Bruce, S.S., Chong, A.M., Claassen, J., Faust, P.L., Hargus, G., Hickman, R.A., Jambawalikar, S., Khandji, A.G., Kim, C.Y., Klein, R.S., Lignelli-Dipple, A., Lin, C.C., Liu, Y., Miller, M.L., Moonis, G., Nordvig, A.S., Overdevest, J.B., Prust, M.L., Przedborski, S., Roth, W.H., Soung, A., Tanji, K., Teich, A.F., Agalliu, D., Uhlemann, A.C., Goldman, J.E. and Canoll, P., 2021, COVID-19 neuropathology at Columbia University Irving Medical Center/New York Presbyterian Hospital. Brain.

191. Piscitelli D, Perin C, Tremolizzo L, Peroni F, Cerri $\mathrm{CG}$, Cornaggia CM. Functional movement disorders in a patient with COVID-19. Neurol Sci. 2020;41:2343-4.

192. Brun G, Hak JF, Coze S, Kaphan E, Carvelli J, Girard N, Stellmann JP. COVID-19-White matter and globus pallidum lesions: demyelination or small-vessel vasculitis? Neurol Neuroimmunol Neuroinflamm. 2020;7(4):e777.

193. Zanin L, Saraceno G, Panciani PP, Renisi G, Signorini L, Migliorati K, Fontanella MM. SARS-CoV-2 can induce brain and spine demyelinating lesions. Acta Neurochir (Wien). 2020;162:1491-4.

194. Sanchez CV, Theel E, Binnicker M, Toledano M, McKeon A. Autoimmune encephalitis post-SARS-CoV-2 infection: case frequency, findings, and outcomes. Neurology. 2021;97(23):e2262-8.

195. Fagyas M, Uri K, Siket IM, Darago A, Boczan J, Banyai E, Edes I, Papp Z, Toth A. New perspectives in the reninangiotensin-aldosterone system (RAAS) III: endogenous inhibition of angiotensin converting enzyme (ACE) provides protection against cardiovascular diseases. PLoS One. 2014;9:e93719. 
196. Banhegyi V, Enyedi A, Fulop GA, Olah A, Siket IM, Varadi C, Bottyan K, Lodi M, Csongradi A, Umar AJ, Fagyas M, Czuriga D, Edes I, Polos M, Merkely B, Csanadi Z, Papp Z, Szabo G, Radovits T, Takacs I, Toth A. Human Tissue Angiotensin Converting Enzyme (ACE) Activity is regulated by genetic polymorphisms, posttranslational modifications, endogenous inhibitors and secretion in the serum, lungs and heart. Cells. 2021;10:71708.

197. Tavassoly O, Safavi F, Tavassoly I. Seeding brain protein aggregation by SARS-CoV-2 as a possible long-term complication of COVID-19 infection. ACS Chem Neurosci. 2020;11:3704-6.

198. Hess DC, Rutkowski E, Morgan J, McCluskey L. COVID-19 and neurological symptoms: is the SARSCoV-2 virus neurotropic? Cond Med. 2020;3:241-5.

199. Iba T, Connors JM, Levy JH. The coagulopathy, endotheliopathy, and vasculitis of COVID-19. Inflamm Res. 2020;69:1181-9.

200. Festoff BW, Citron BA. Thrombin and the coag-inflammatory nexus in neurotrauma, ALS, and other neurodegenerative disorders. Front Neurol. 2019;10:59.

201. Al-Dalahmah O, Thakur KT, Nordvig AS, Prust ML, Roth W, Lignelli A, Uhlemann AC, Miller EH, KunnathVelayudhan S, Del Portillo A, Liu Y, Hargus G, Teich AF, Hickman RA, Tanji K, Goldman JE, Faust PL, Canoll P. Neuronophagia and microglial nodules in a SARSCoV-2 patient with cerebellar hemorrhage. Acta Neuropathol Commun. 2020;8:147.

202. Lee MH, Perl DP, Nair G, Li W, Maric D, Murray H, Dodd SJ, Koretsky AP, Watts JA, Cheung V, Masliah E, Horkayne-Szakaly I, Jones R, Stram MN, Moncur J, Hefti M, Folkerth RD, Nath A. Microvascular injury in the brains of patients with COVID-19. N Engl J Med. 2021;384:481-3.

203. Fernandez-Castaneda, A., Lu, P., Geraghty, A.C., Song, E., Lee, M.H., Wood, J., Yalcin, B., Taylor, K.R., Dutton, S., Acosta-Alvarez, L., Ni, L., Contreras-Esquivel, D., Gehlhausen, J.R., Klein, J., Lucas, C., Mao, T., Silva, J., Pena-Hernandez, M.A., Tabachnikova, A., Takahashi, T., Tabacof, L., Tosto-Mancuso, J., Breyman, E., Kontorovich, A., McCarthy, D., Quezado, M., Hefti, M., Perl, D., Folkerth, R., Putrino, D., Nath, A., Iwasaki, A. and Monje, M., 2022, Mild respiratory SARS-CoV-2 infection can cause multi-lineage cellular dysregulation and myelin loss in the brain. bioRxiv.

204. Erdo F, Denes L, de Lange E. Age-associated physiological and pathological changes at the blood-brain barrier: A review. J Cereb Blood Flow Metab. 2017;37:4-24.

205. Wang C, Zhang M, Garcia G, Jr Tian E, Cui Q, Chen X, Sun G, Wang J, Arumugaswami V, Shi Y. ApoE-isoform-dependent SARS-CoV-2 neurotropism and cellular response. Cell Stem Cell. 2021a;28(331):342-e335.
206. Zhao Y, Li W, Lukiw W. Ubiquity of the SARS-CoV-2 receptor ACE2 and upregulation in limbic regions of Alzheimer's disease brain. Folia Neuropathol. 2021;59:232-8.

207. Siddiqi HK, Libby P, Ridker PM. COVID-19 - a vascular disease. Trends Cardiovasc Med. 2021;31:1-5.

208. Li Y, Xie L, Huang T, Zhang Y, Zhou J, Qi B, Wang X, Chen Z, Li P. Aging Neurovascular Unit and Potential Role of DNA Damage and Repair in Combating Vascular and Neurodegenerative Disorders. Front Neurosci. 2019;13:778.

209. Min LJ, Mogi M, Shudou M, Jing F, Tsukuda K, Ohshima K, Iwanami J, Horiuchi M. Peroxisome proliferator-activated receptor-gamma activation with angiotensin II type 1 receptor blockade is pivotal for the prevention of blood-brain barrier impairment and cognitive decline in type 2 diabetic mice. Hypertension. 2012;59:1079-88.

210. Luijten, L.W.G., Leonhard, S.E., van der Eijk, A.A., Doets, A.Y., Appeltshauser, L., Arends, S., Attarian, S., Benedetti, L., Briani, C., Casasnovas, C., Castellani, F., Dardiotis, E., Echaniz-Laguna, A., Garssen, M.P.J., Harbo, T., Huizinga, R., Humm, A.M., Jellema, K., van der Kooi, A.J., Kuitwaard, K., Kuntzer, T., Kusunoki, S., Lascano, A.M., Martinez-Hernandez, E., Rinaldi, S., Samijn, J.P.A., Scheidegger, O., Tsouni, P., Vicino, A., Visser, L.H., Walgaard, C., Wang, Y., Wirtz, P.W., Ripellino, P., Jacobs, B.C. and consortium, I., 2021, GuillainBarre syndrome after SARS-CoV-2 infection in an international prospective cohort study. Brain.

211. Manji HK, George U, Mkopi NP, Manji KP. GuillainBarre syndrome associated with COVID-19 infection. Pan Afr Med J. 2020;35:118.

212. Sullivan BN, Fischer T. Age-Associated Neurological complications of COVID-19: a systematic review and meta-analysis. Front Aging Neurosci. 2021;13:653694.

213. Hampshire A, Zadel A, Sandrone S, Soreq E, Fineberg N, Bullmore ET, Robbins TW, Sahakian BJ, Chamberlain SR. Inhibition-related cortical hypoconnectivity as a candidate vulnerability marker for obsessive-compulsive disorder. Biol Psychiatry Cogn Neurosci Neuroimaging. 2020;5:222-30.

Publisher's note Springer Nature remains neutral with regard to jurisdictional claims in published maps and institutional affiliations. 